https://helda.helsinki.fi

\title{
Food Additives as Inhibitors of Intestinal Drug Transporter OATP2B1
}

\section{Tikkanen, Alli}

2020-10-05

Tikkanen , A , Pierrot , E , Deng , F , Sanchez , V B , Hagström , M , Koenderink , J B \&

Kidron , H 2020 , ' Food Additives as Inhibitors of Intestinal Drug Transporter OATP2B1 ' , Molecular Pharmaceutics, vol. 17 , no. 10 , pp. 3748-3758 . https://doi.org/10.1021/acs.molpharmaceut.0c00507

http://hdl.handle.net/10138/333627

https://doi.org/10.1021/acs.molpharmaceut.0c00507

acceptedVersion

Downloaded from Helda, University of Helsinki institutional repository.

This is an electronic reprint of the original article.

This reprint may differ from the original in pagination and typographic detail.

Please cite the original version. 


\title{
FOOD ADDITIVES AS INHIBITORS OF INTESTINAL DRUG TRANSPORTER OATP2B1
}

\author{
Alli Tikkanen ${ }^{1}$, Estelle Pierrot ${ }^{1}$, Feng Deng ${ }^{1,2}$, Virginia Barras Sánchez ${ }^{1}$, Marja Hagström ${ }^{1}, J_{a n}$ B. Koenderink ${ }^{3}$, \\ Heidi Kidron ${ }^{1 *}$ \\ ${ }^{1}$ Division of Pharmaceutical Biosciences, Faculty of Pharmacy, University of Helsinki, P.O. Box 56, 00014 \\ Helsinki, Finland \\ ${ }^{2}$ Current address: Department of Clinical Pharmacology, Faculty of Medicine, University of Helsinki \\ ${ }^{3}$ Radboud University Medical Center, Department of Pharmacology and Toxicology, Nijmegen, The \\ Netherlands \\ *corresponding author \\ Telephone: +358405666660 \\ Email: heidi.kidron@helsinki.fi
}




\section{FOR TABLE OF CONTENTS USE ONLY}

FOOD ADDITIVES AS INHIBITORS OF INTESTINAL DRUG TRANSPORTER OATP2B1

Alli Tikkanen, Estelle Pierrot, Feng Deng, Virginia Barras Sánchez, Marja Hagström, Jan B. Koenderink, Heidi Kidron

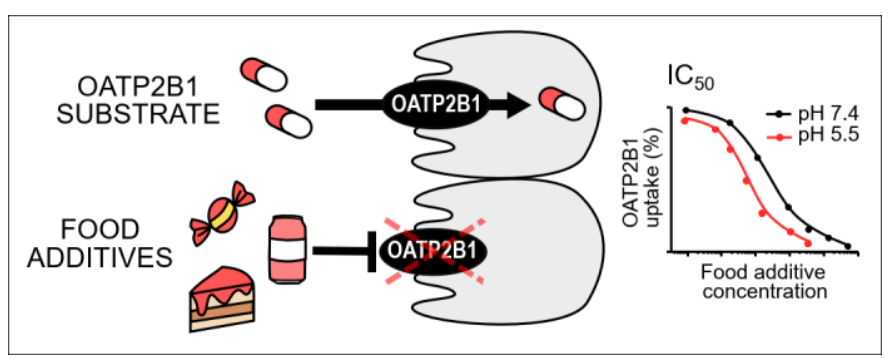




\section{ABSTRACT}

Food additives are compounds that are added to food and beverage to improve taste, color, preservation or composition. Generally, food additives are considered safe for human use due to safety evaluation conducted by food safety authorities and high safety margins applied to permitted usage levels. However, the interaction potential of food additives with simultaneously administered medication has not received much attention. Even though many food additives are poorly absorbed into systemic circulation, high concentrations could exist in the intestinal lumen making intestinal drug transporters, such as the uptake transporter organic anion transporting polypeptide 2B1 (OATP2B1), a possible site of food additive-drug interaction. In the present work, we aimed to characterize the interaction of a selection of 25 food additives including colorants, preservatives and sweeteners with OATP2B1 in vitro. In HEK293 cells transiently overexpressing OATP2B1 or control, uptake of dibromofluorescein was studied with and without $50 \mu \mathrm{M}$ food additive at $\mathrm{pH}$ 7.4. As OATP2B1 displays substrateand $\mathrm{pH}$-dependent transport function and the intraluminal $\mathrm{pH}$ varies along the gastrointestinal tract, we performed the studies also at $\mathrm{pH} 5.5$ using estrone sulfate as OATP2B1 substrate. Food additives that inhibited OATP2B1mediated substrate transport with $\geq 50 \%$ were subjected to dose-response studies. Six colorants were identified and validated as OATP2B1 inhibitors at $\mathrm{pH}$ 5.5, but only three of these were categorized as inhibitors at $\mathrm{pH}$ 7.4. One sweetener was validated as an inhibitor at both assay conditions whereas none of the preservatives exhibited $\geq 50 \%$ inhibition of OATP2B1-mediated transport. Extrapolation of computed inhibitory constants ( $\mathrm{K}_{\mathrm{i}}$ values) to estimations of intestinal food additive concentrations imply that selected colorants could inhibit intestinal OATP2B1 also in vivo. These results suggest that food additives, especially colorants, could alter the pharmacokinetics of orally administered OATP2B1 substrate drugs, although further in vivo studies are warranted to understand the overall clinical consequences of the findings.

\section{KEYWORDS}

drug transporter; organic anion transporting polypeptide; OATP2B1; food additives; food-drug interaction

\section{ABBREVIATIONS}

ABC-transporter, ATP-binding cassette transporter

ADI, acceptable daily intake

BCRP, breast cancer resistance protein $(A B C G 2)$

DBF, 4', 5'-dibromofluorescein

EFSA, European Food Safety Authority

eYFP, enhanced yellow fluorescence protein

GI, gastrointestinal

HEK293, human embryonic kidney 293 cells

$\mathrm{IC}_{50}$, half-maximal inhibitory concentration

$\mathrm{K}_{\mathrm{i}}$, inhibition constant

MRP2, multidrug resistance associated protein 2

OATP2B1, organic anion transporting polypeptide 2B1 (SLCO2B1)

P-gp, P-glycoprotein 


\section{INTRODUCTION}

Food additives are substances widely added to processed food to improve their taste, color, preservation or composition. In the European Union, the use of food additives is controlled by legislation (Regulation (EC) No 1333/2008 of the European Parliament and Council). The European Food Safety Authority (EFSA) evaluates the safety and establishes acceptable daily intake (ADI), defined as the safe amount of food additive to be consumed daily, for each food additive. The evaluation of food additive safety by authorities as well as scientific research has mainly focused on toxicity issues such as acute and chronic toxicity, carcinogenicity, genotoxicity, developmental and reproductive toxicity and hypersensitivity. ${ }^{1}$ However, the interaction potential of food additives with concurrently administered medication has not received much attention. Interindividual variability in drug pharmacokinetics is a major concern affecting especially drugs with narrow therapeutic range, and food-drug interactions are known to be a source of variability in many circumstances. ${ }^{2}$ Even though many food additives are poorly absorbed and hardly reach the systemic circulation, ${ }^{1}$ they could affect drug pharmacokinetics by altering the function of drug transporters they encounter during gastrointestinal (GI) transit.

It is increasingly acknowledged that pharmaceutical excipients used for drug formulation, some of which are also used as food additives, are not pharmacokinetically inert as they can interact with GI phase I and phase II metabolizing enzymes as well as drug transporters. ${ }^{3,4}$ For example, in different cell and animal models, the major intestinal ATP-binding cassette (ABC) drug transporters, P-glycoprotein (P-gp), breast cancer resistance protein (BCRP) and multidrug resistance associated protein 2 (MRP2), are inhibited by excipients such as the surfactants Cremophor EL, Tween 20 or Tween $80 .{ }^{3}$ Previously in our group, we identified several colorants capable of inhibiting BCRP and MRP2 in vitro with low micromolar $\mathrm{IC}_{50}$ values. ${ }^{5}$ Also others have reported similar results for the inhibition of BCRP. ${ }^{6}$ Even though drug formulations infrequently contain high amounts of these additives, higher concentrations may be present in food products. For example, in extreme cases, the intestinal concentrations after dietary exposure of selected azo dyes could exceed BCRP and MRP2 IC 50 values more than 100-fold, suggesting that also in vivo inhibition of these transporters could occur. ${ }^{5}$ In addition to intestinal efflux transporters, cellular uptake transporters localized on the membrane facing the intestinal lumen could be exposed to high food additive concentrations and, thus, be a site of food additive-drug interaction. However, knowledge about the impact of drug or food additives on the function of uptake transporters is limited. ${ }^{3,4}$ In a few studies, pharmaceutical excipients, such as solubilizing agents hydroxypropyl- $\beta$-cyclodextrin, Solutol HS 15 and Cremophor EL, have been shown to inhibit the main intestinal organic anion transporting polypeptide (OATP), OATP2B1, and other intestinal drug uptake transporters. ${ }^{7,8}$

OATP2B1, encoded by the $S L C O 2 B 1$ gene, is expressed widely in many tissues including liver hepatocytes and importantly, along the entire intestine. ${ }^{9,10}$ However, there are contradicting findings regarding the apical or basolateral localization of the transporter in enterocytes. ${ }^{11,12}$ OATP2B1 accepts a wide range of drugs as its substrate in vitro, such as the antihistamine fexofenadine, lipid-lowering agents fluvastatin and rosuvastatin, and anti-inflammatory drug sulfasalazine. ${ }^{10}$ Even though the evaluation of the role of OATP2B1 in drug pharmacokinetics has quickly evolved in recent years, this research is relatively new compared to other drug transporters, and currently the evidence of OATP2B1 contribution to drug-drug interactions is limited. ${ }^{13}$ However, intestinal OATP2B1 is recognized as a mediator of several clinical food-drug interactions, where inhibition of OATP2B1 by common fruit juices has decreased the oral bioavailability of OATP2B1 substrates, such as aliskiren, celiprolol and fexofenadine, with more than $60 \% .^{14-16}$ The involvement of OATP2B1 on drug absorption is supported by studies where the genetic variant $S L C O 2 B 1-\mathrm{c} .1457 \mathrm{C}>\mathrm{T}$ (rs2306168) has been associated to decreased intestinal absorption of fexofenadine and celiprolol. ${ }^{14,15}$ In addition, recent knockout studies in mice suggest that the mouse orthologue for OATP2B1, Oatp2b1, is involved in the oral absorption of OATP2B1 substrates fexofenadine and fluvastatin. ${ }^{17,18}$ With this background, the International Transporter Consortium (ITC) 
introduced OATP2B1 as a clinically emerging transporter for drug development and recommended at least retrospective evaluation of OATP2B1 contribution to drug pharmacokinetics. ${ }^{19}$

Considering the emerging clinical significance of OATP2B1 and the gap in knowledge on food additive-drug interactions, the aim of this study was to characterize the potential of a set of food additives to inhibit OATP2B1 in vitro. The selected 25 food additives included 9 colorants, 6 preservatives and 10 sweeteners commonly used in Europe, and have been previously examined for intestinal efflux transporter inhibition. ${ }^{5}$ As OATP2B1 displays substrate- and $\mathrm{pH}$-dependent transport function, ${ }^{12,20,21}$ we performed studies at $\mathrm{pH} 5.5$ in addition to standard assay conditions at $\mathrm{pH} 7.4$ and used the endogenous OATP2B1 substrate estrone sulfate and fluorescent substrate dibromofluorescein (DBF), respectively, as OATP2B1 probes. Finally, comparison of calculated inhibitory constants with estimations of intestinal food additive concentrations reveal that in vivo inhibition of intestinal OATP2B1 cannot be excluded. 


\section{MATERIALS AND METHODS}

\section{Materials}

Food additives and other chemicals were purchased from Sigma-Aldrich (St. Louis, MO, USA) unless otherwise stated. All food additives had $\geq 96 \%$ purity except betanin, curcumin $(\geq 65 \%)$ and Sunset Yellow FCF (dye content 90\%). The food additives were dissolved in DMSO at 4-20 mM. Dulbeccos's modified eagle medium (DMEM; high glucose, GlutaMAX Supplement), Hank's balanced salt solution (HBSS) and fetal bovine serum (FBS) were obtained from Thermo Fisher Scientific (Waltham, MA, USA). $\left[{ }^{3} \mathrm{H}\right]$-Estrone sulfate ammonium salt (specific activity range $40-60 \mathrm{Ci} / \mathrm{mmol}$ ) and Optiphase Hisafe 3 scintillation liquid were from PerkinElmer (Boston, MA, USA).

\section{Preparation of $S L C O 2 B 1$ carrying vectors}

The full length protein coding sequence of SLCO2B1 (NCBI Reference Sequence: NM_007256.5) was cloned with polymerase chain reaction (PCR) from human adult normal liver tissue (BioChain, San Francisco, CA, USA). The primers were 5'-TGCAGTCGACCAGTCATGGGACCCAG-3' and 5'GAGGATTCCCGAGTGTGAGAATTCTTGGG-3' and were designed to contain SalI and EcoRI restriction sites, which were used to clone the insert into Gateway pENTR4 dual selection vector with T4 DNA Ligase (Thermo Fisher Scientific). For eukaryotic translation initiation, a kozak consensus sequence (GCC GCC ACC) was added in front of the translation initiation codon with site-directed mutagenesis (Q5 Site-Directed Mutagenesis Kit, New England Biolabs, Ipswich, MA, USA). Eurofins Genomics sequencing service (Edersberg, Germany) was used to verify the correct sequence of SLCO2B1.

Preparation of recombinant SLCO2B1 carrying baculoviruses for transient expression of OATP2B1 in HEK293 cells was conducted according to manufacturer's protocols (Bac-to-Bac Baculovirus Expression System and ViraPower BacMam Expression System from Thermo Fisher Scientific) and as previously described for $A B C G 2{ }^{22}$ In brief, from the pENTR4 entry vector, the $S L C O 2 B 1$ gene was transferred into a modified Bac-to-Bac destination vector with Gateway LR Clonase II enzyme mix (Thermo Fisher Scientific). Purified plasmid construct was transformed into competent DH10Bac E. Coli cells for transposition into bacmid. Cellfectin II reagent (Thermo Fisher Scientific) was used to transfect adherent Sf9 cells with recombinant bacmid DNA. The cells were incubated for seven days at $27{ }^{\circ} \mathrm{C}$ before harvesting recombinant baculovirus. This P1 viral stock was further amplified to yield P2 and P3 baculovirus stocks by infecting Sf9 cells with the harvested baculovirus and incubating for seven days at $27^{\circ} \mathrm{C}$. Baculovirus containing the gene for enhanced yellow fluorescence protein (eYFP) were produced similarly to be used as negative control in the HEK293 uptake assay.

\section{HEK293 uptake assay}

HEK293 cells were routinely cultured in DMEM supplemented with $10 \% \mathrm{FBS}$ at $37{ }^{\circ} \mathrm{C}$ and $5 \% \mathrm{CO}_{2}$. For the uptake assay, HEK293 cells were seeded at 50000 cells/well on Nunclon Delta Surface 48-well plates (Thermo Fisher Scientific) coated with poly-D-lysine, or CellBind 48-well plates (Corning, NY, USA) and incubated overnight at $37{ }^{\circ} \mathrm{C}$ and $5 \% \mathrm{CO}_{2}$. The growth medium was replaced with transduction mix with $5 \mathrm{mM}$ sodium butyrate and recombinant SLCO2B1 or eYFP (control) P3 baculovirus in DMEM supplemented with 10\% FBS.

The uptake assay was initiated approximately 48 hours later by pre-incubating cells with transport buffer with $\mathrm{pH}$ 7.4 or $\mathrm{pH} 5.5$ for 5 minutes at $37^{\circ} \mathrm{C}$. The transport buffer was composed of $25 \mathrm{mM}$ HEPES (pH 7.4) or MES (pH 5.5) and $4.17 \mathrm{mM} \mathrm{NaHCO}_{3}$ in $\mathrm{HBSS}$ adjusted to the assigned $\mathrm{pH}$ with $\mathrm{NaOH}$. After the pre-incubation, transport buffer was replaced with test solution containing OATP2B1 probe substrate in transport buffer, and incubated at $37{ }^{\circ} \mathrm{C}$ while keeping the assay plate well-stirred in an orbital shaker. The uptake was terminated by washing cells three times with ice-cold transport buffer. Probe substrates used were $4^{\prime}, 5^{\prime}$-dibromofluorescein (DBF) at pH 7.4, 
and estrone sulfate at $\mathrm{pH}$ 5.5. A range of substrate concentrations and incubation times were tested to find the linear part of substrate transport.

The set of food additives was tested for OATP2B1 inhibition at $50 \mu \mathrm{M}$ concentration. DMSO concentration of test solution was kept below $1.5 \%$. Concentrations and incubation times of OATP2B1 substrates were chosen from the linear transport zone and were $1 \mu \mathrm{M}$ (5 minutes) and $0.5 \mu \mathrm{M}(2-3$ minutes) for DBF and estrone sulfate, respectively. Food additives that inhibited OATP2B1-mediated transport of substrate with $\geq 50 \%$ were selected for dose-response studies for half-maximal inhibitory concentration $\left(\mathrm{IC}_{50}\right)$ determination.

\section{Sample analysis}

DBF samples. Cells were lysed with $0.1 \mathrm{M} \mathrm{NaOH}$ for 10 minutes before measuring cellular drug accumulation. DBF lysates were analyzed with fluorescence detection using Varioskan LUX microplate reader (Thermo Fisher Scientific) with $503 \mathrm{~nm}$ excitation and $525 \mathrm{~nm}$ emission.

Estrone sulfate samples. Inhibition and optimization studies with estrone sulfate were performed with radiolabeled substrate whereas LC-MS/MS detection was used to determine transport kinetics of estrone sulfate due to high consumption of substrate. $\left[{ }^{3} \mathrm{H}\right]$-Estrone sulfate containing cells were lysed in $0.1 \mathrm{M} \mathrm{NaOH}$ and subsequently neutralized with equivalent moles of $1 \mathrm{M} \mathrm{HCl}$ before adding Optiphase HiSafe 3 scintillation liquid and measuring radioactivity of samples with MicroBeta 2450 Microplate Counter (PerkinElmer). Estrone sulfate from transport kinetics samples were quantitated with ultra-high pressure liquid chromatography tandem mass spectrometry instrument (UPLC-MS/MS) (Waters, MA, USA). Cells were lysed with 3:1 methanol-water solution containing $25 \mathrm{ng} / \mathrm{mL}$ estrone sulfate D5 as internal standard (ISTD). After incubation for 30 minutes, the lysates were centrifuged at $14000 \mathrm{~g}$ for 10 minutes. Analytes in the supernatant were separated on a liquid chromatography coupled with Waters UPLC HSS T3 column $(1.8 \mu \mathrm{m}, 2.1 \times 100 \mathrm{~mm})$ at $40^{\circ} \mathrm{C}$, while injection volume was $1 \mu \mathrm{L}$. Mobile phase consisted of $0.1 \%$ of formic acid (Merck, Darmstadt, Germany) in ultrapure water (A) and $100 \%$ of LC-MS grade acetonitrile (Honeywell, Seelze, Germany) (B). Gradient elution started with $20 \%$ of B at $0-0.5$ minutes, continued with $20-95 \%$ B at $0.5-2$ minutes, while complete run time was 5 minutes including column wash and equilibration. The flow rate was set to $0.4 \mathrm{~mL} / \mathrm{min}$.

Mass spectrometric measurements were carried out using Waters Xevo TQ-S triple quadrupole mass spectrometer coupled with an electrospray ionization (ESI) on a negative mode. Optimized ms-parameters were as follows: capillary $1.5 \mathrm{kV}$, cone voltage $80 \mathrm{~V}$ for estrone sulfate and $86 \mathrm{~V}$ for ISTD, source temperature $150{ }^{\circ} \mathrm{C}$ and desolvation temperature $600{ }^{\circ} \mathrm{C}$. Nitrogen (AGA, Helsinki, Finland) was used as desolvation gas $\left(600 \mathrm{~L} \mathrm{~h}^{-1}\right)$ and cone gas $\left(150 \mathrm{~L} \mathrm{~h}^{-1}\right)$, and argon (AGA) as collision gas. The multiple reaction monitoring mode was employed for quantification. Precursor and fragment ions were for estrone sulfate 349.02> 269.35 (collision energy (CE) $31 \mathrm{~V}$ ) and for ISTD $354.05>274.36$ (CE 32 V). Resulting data was analyzed with Waters MassLynx V4.1 software.

\section{$\underline{\text { Data analysis }}$}

OATP2B1-mediated uptake of substrates was calculated by subtracting background passive uptake obtained from eYFP transduced control wells and normalizing to test solution incubation time and average total protein amount in wells (typically 0.02-0.10 mg/well) measured with Pierce Coomassie (Bradford) Assay kit (ThermoFisher Scientific). The percentage of OATP2B1-mediated uptake inhibited by the food additives was obtained by normalizing the uptake of substrate to control, where cells were incubated with substrate only.

The $\mathrm{IC}_{50}$ values were calculated with GraphPad Prism version 6.07 (GraphPad Software, San Diego, CA, USA) by fitting the data to the four parameter dose-response curve (eq. 1). 


$$
\text { Substrate uptake }(\% \text { of control })=\text { Bottom }+\frac{\text { Top }- \text { Bottom }}{1+\left(\frac{[\mathrm{I}]}{\mathrm{IC}_{50}}\right)^{\text {Hill Slope }}}
$$

According to the model, bottom and top values are the maximum and minimum plateaus of the curve. The bottom plateau was constrained to zero, and, if necessary, top value to 100. [I] is the inhibitor concentration, and the Hill Slope describes the steepness of the curve. Inhibition constant $\left(\mathrm{K}_{\mathrm{i}}\right)$ values were extrapolated from the $\mathrm{IC}_{50}$ values according to the Cheng-Prusoff equation (eq. 2) assuming that inhibition mode is competitive and only one substrate/inhibitor binding site is involved. ${ }^{23,24}$ However, it should be noted that multiple binding sites on OATP2B1 exist. ${ }^{21,25}$

$$
\mathrm{K}_{\mathrm{i}}=\frac{\mathrm{IC}_{50}}{1+\frac{[\mathrm{S}]}{\mathrm{K}_{\mathrm{m}}}}
$$

In eq. 2, [S] is the substrate concentration and $\mathrm{K}_{\mathrm{m}}$ is the Michaelis-Menten constant. The $\mathrm{K}_{\mathrm{m}}$ values for OATP2B1mediated transport of DBF at pH 7.4 and estrone sulfate at $\mathrm{pH} 5.5$ were defined with the HEK293 uptake assay by measuring substrate uptake in OATP2B1 and control transduced cells with different substrate concentrations and fitting the data with non-linear regression with Graphpad Prism.

Molecular properties of compounds were calculated with ACD/Labs version 8.0 (Advanced Chemistry Development, Inc., Toronto, ON, Canada).

\section{Assay interference studies}

Assay interference studies were performed as previously described ${ }^{5}$ to exclude false positive or negative results due to aggregation of food additives, intrinsic fluorescence of food additives or quenching of DBF fluorescence signal. Aggregation of $50 \mu \mathrm{M}$ food additives in the transport buffer at $\mathrm{pH} 7.4$ and $\mathrm{pH} 5.5$ was tested using Nepheloskan Ascent nephelometer (Thermo Fisher Scientific). When aggregation was observed, further dilutions of the food additives were made to find solubility limits. Quenching of DBF fluorescence or intrinsic fluorescence of food additives were assayed by mimicking the assay conditions by measuring the fluorescence of $0.1 \mu \mathrm{M}$ DBF with $50 \mu \mathrm{M}$ food additive in $0.1 \mathrm{M} \mathrm{NaOH}$. These conditions assume that all of the food additive in the inhibition assay would be taken up by the cells and retained in the final sample elute, which is not likely. If fluorescence interference was observed in these conditions, DBF fluorescence was measured together with lower concentrations of food additives assuming that $20 \%(10 \mu \mathrm{M}), 10 \%(5 \mu \mathrm{M})$ or $2 \%(1 \mu \mathrm{M})$ of the initial $50 \mu \mathrm{M}$ food additive would be retained in the final fluorescence sample.

\section{Statistical analysis}

The single concentration $(50 \mu \mathrm{M})$ food additive testing was performed once with three replicate wells. The $\mathrm{IC}_{50}$ assays were repeated on 3-4 independent occasions with three replicates each $(n=3-4)$. Kinetic assays were performed once with three replicate wells.

Statistical significance was calculated with unpaired student's $t$-test or when multiple groups were compared, oneway ANOVA with Tukey's or Dunnett's post hoc test. Statistical significance was considered when $p<0.05$. 


\section{RESULTS}

The uptake of DBF into OATP2B1 and control (eYFP) transduced HEK293 cells was studied at pH 7.4. OATP2B1-mediated uptake of DBF was time- (Supporting Information Figure S1) and concentration-dependent with a $\mathrm{K}_{\mathrm{m}}$ value of $2.7 \pm 0.29 \mu \mathrm{M}$ (Figure 1A). High passive background uptake of DBF (apparent pKa 6.69 [most acidic]; $\log \mathrm{D}_{5.5} 4.87$ ) in control transduced cells at $\mathrm{pH} 5.5$ impeded the use DBF as OATP2B1 substrate at this $\mathrm{pH}$ (data not shown). Estrone sulfate (pKa not applicable; $\log \mathrm{D}_{5.5} 0.01$ ) demonstrated time- (Supporting Information Figure S1) and concentration-dependent OATP2B1-mediated uptake with low background uptake and a $\mathrm{K}_{\mathrm{m}}$ value of $12.9 \pm 3.2 \mu \mathrm{M}$ at pH 5.5 (Figure 1B). The transport affinity of both substrates was comparable with previously published data. ${ }^{26-28}$
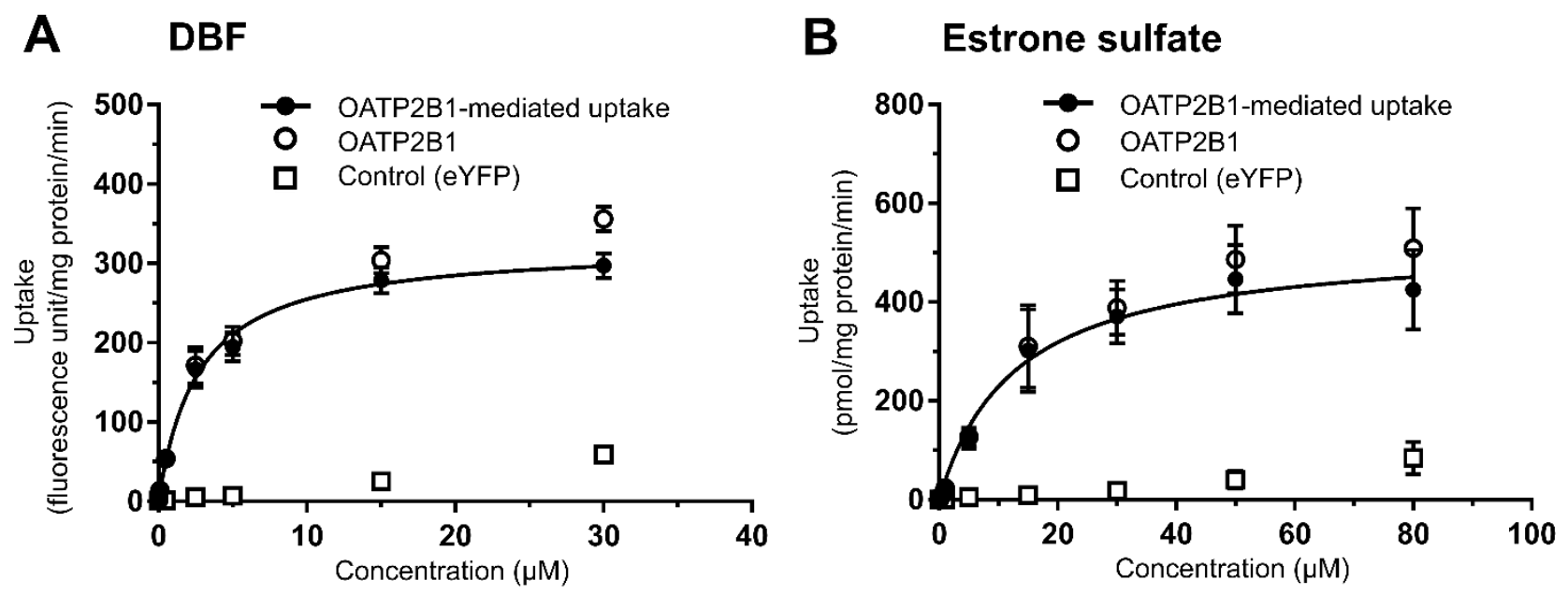

Figure 1. Concentration-dependent uptake of (A) dibromofluorescein (DBF) and (B) estrone sulfate into HEK293 cells expressing OATP2B1 ( $)$ ) or control ( $\square$ ). OATP2B1-mediated uptake $(\bullet)$ was obtained by subtracting control uptake from OATP2B1 uptake. Uptake of DBF was studied at pH 7.4 over 5 minutes and uptake of estrone sulfate at $\mathrm{pH} 5.5$ over 2 minutes. The data is presented as mean \pm SD from one study with three replicate wells. Data used to create the figures is presented in Supporting Information Table S1 and S2.

The potential to inhibit OATP2B1-mediated uptake of DBF at $\mathrm{pH} 7.4$ and estrone sulfate at $\mathrm{pH} 5.5$ was tested for a set of 25 food additives at $50 \mu \mathrm{M}$ concentration (Figure 2 and Supporting Information Table S4). Three of the colorants (Allura Red AC, Carmoisine and curcumin) inhibited OATP2B1-mediated transport of DBF and estrone sulfate with $\geq 50 \%$. Three additional colorants (Brilliant Black BN, Brilliant Blue FCF and Sunset Yellow FCF) were characterized as inhibitors only when estrone sulfate was used as substrate. None of the preservatives inhibited OATP2B1-mediated transport with over 50\% compared to the control. Neohesperidin dihydrochalcone (DC) was the only sweetener identified as an OATP2B1 inhibitor at both assay conditions while rebaudioside A inhibited OATP2B1-mediated DBF uptake $\geq 50 \%$. Sucralose seemed to increase OATP2B1 mediated uptake of DBF as uptake was $153.5 \pm 8.9 \%$ compared to control. 

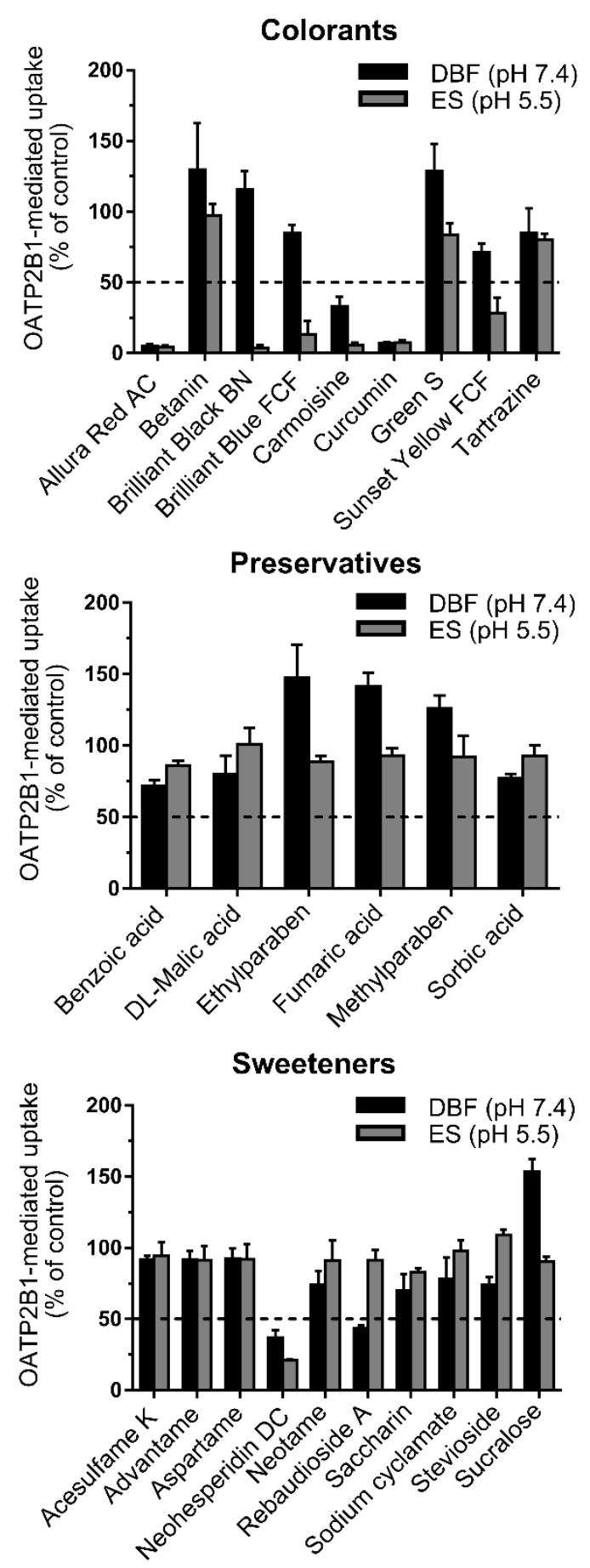

Figure 2. Inhibition of OATP2B1-mediated uptake of $1 \mu \mathrm{M}$ dibromofluorescein (DBF) at $\mathrm{pH} 7.4$ (black bars) or $0.5 \mu \mathrm{M}$ estrone sulfate (ES) at $\mathrm{pH} 5.5$ (gray bars) by a selection of 25 food additives including colorants, preservatives and sweeteners. OATP2B1 and control overexpressing HEK293 cells were incubated with $50 \mu \mathrm{M}$ food additive and substrate to define percent of OATP2B1 uptake inhibited. Food additives that inhibited OATP2B1-mediated uptake more than 50\% (dashed line) were selected for dose-response studies. The results are expressed as mean \pm SD (in three replicate wells) of OATP2B1-mediated uptake normalized to control without food additive. 
Based on the initial single inhibitor concentration assay, potential OATP2B1 inhibitors were selected for doseresponse studies to determine $\mathrm{IC}_{50}$ (Figure 3 and Table 1), which were then used to extrapolate $\mathrm{K}_{\mathrm{i}}$ values according to the Cheng-Prusoff equation. Because substrate concentrations used were well below $\mathrm{K}_{\mathrm{m}}$ values, the calculated $\mathrm{K}_{\mathrm{i}}$ values were close to the $\mathrm{IC}_{50}$ values determined experimentally. Allura Red AC was identified as the strongest inhibitor at both conditions with $\mathrm{K}_{\mathrm{i}}$ values $0.6 \pm 0.3 \mu \mathrm{M}$ and $1.5 \pm 0.5 \mu \mathrm{M}$ at $\mathrm{pH} 7.4$ and $\mathrm{pH} 5.5$, respectively. Rebaudioside A inhibited OATP2B1-mediated uptake of DBF ( $\mathrm{pH} 7.4$ ) with $\geq 50 \%$ at $50 \mu \mathrm{M}$ concentration (Figure 2), but dose-dependent inhibition was not observed (data not shown). The $\mathrm{K}_{\mathrm{i}}$ value of Carmoisine was significantly lower at $\mathrm{pH} 5.5$ compared to $\mathrm{pH} 7.4(p=0.013)$, while Allura Red AC, curcumin and neohesperidin DC had comparable inhibitor profiles at $\mathrm{pH} 7.4$ and $\mathrm{pH} 5.5(p>0.05)$. 

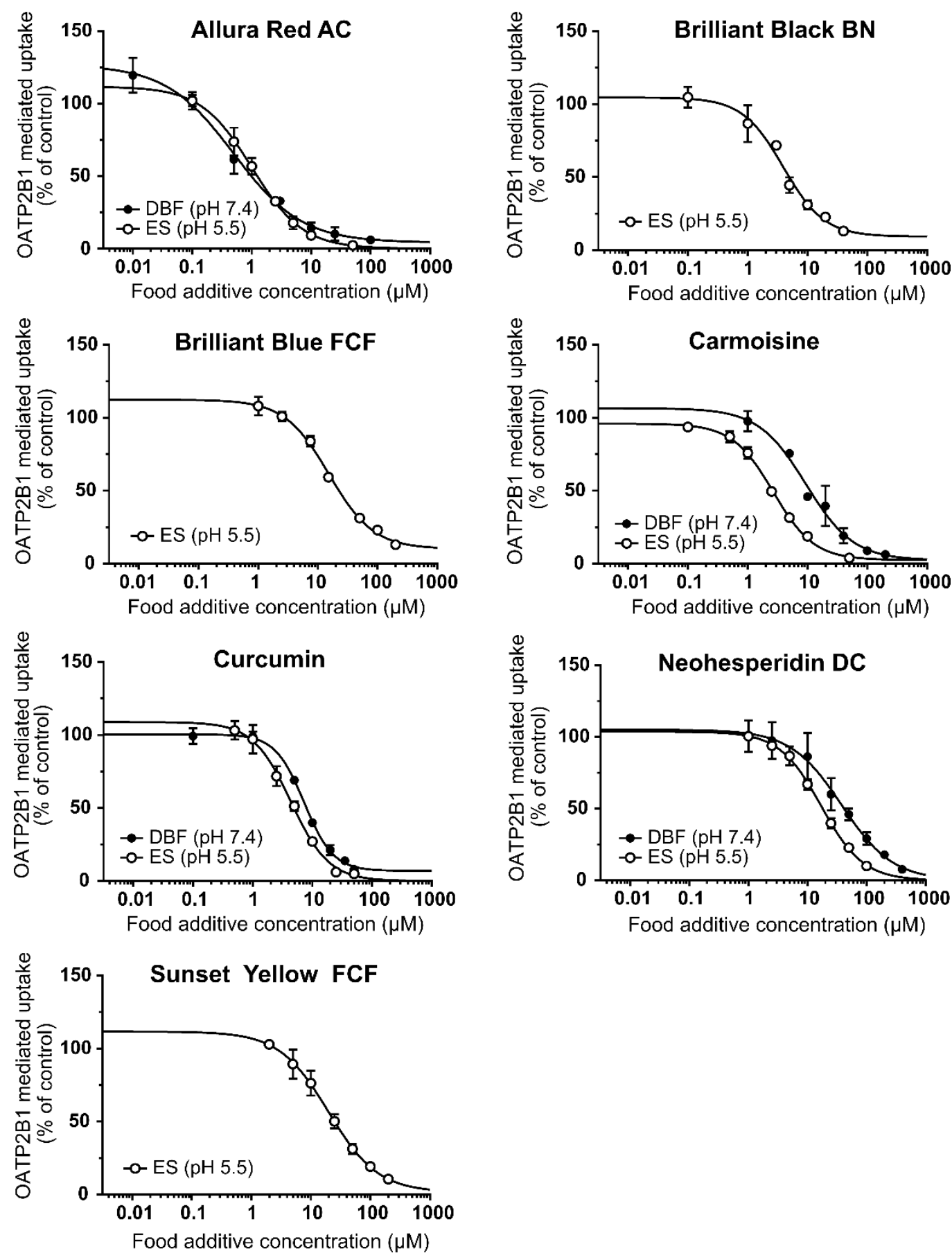

Figure 3. Inhibitory curves of OATP2B1-mediated uptake of $1 \mu \mathrm{M}$ dibromofluorescein (DBF) at $\mathrm{pH} 7.4(\bullet)$ and $0.5 \mu \mathrm{M}$ estrone sulfate at $\mathrm{pH} 5.5(\mathrm{O})$ by selected food additives in HEK293 overexpression system. Brilliant Black BN, Brilliant Blue FCF and Sunset Yellow FCF were characterized as inhibitors only at pH 5.5. Data is presented as mean \pm SD from a representative study with three replicate wells. 
Table 1. Half-maximal inhibitory concentrations $\left(\mathrm{IC}_{50}\right)$ and extrapolated inhibition constant $\left(\mathrm{K}_{\mathrm{i}}\right)$ values for selected food additives at $\mathrm{pH} 7.4$ (DBF as substrate) and $\mathrm{pH} 5.5$ (estrone sulfate). $\mathrm{IC}_{50}$ are expressed as mean $\pm \mathrm{SD}$ calculated from values obtained from 3-4 individual experiments $(n=3-4)$ with three replicate wells. $\mathrm{K}_{\mathrm{i}}$ values were calculated from the $\mathrm{IC}_{50}$ values with the Cheng-Prusoff equation. ${ }^{23,24}$

\begin{tabular}{llll}
\hline Food additive & & $\begin{array}{l}\text { pH 7.4 } \\
(\mu \mathrm{M})\end{array}$ & $\begin{array}{l}\text { pH 5.5 } \\
(\mu \mathrm{M})\end{array}$ \\
\hline Allura Red AC & $\mathrm{IC}_{50}$ & $0.8 \pm 0.4$ & $1.6 \pm 0.6$ \\
& $\mathrm{~K}_{\mathrm{i}}$ & $0.6 \pm 0.3$ & $1.5 \pm 0.5$ \\
Brilliant Black BN & $\mathrm{IC}_{50}$ & $\mathrm{a}$ & $3.9 \pm 0.4$ \\
& $\mathrm{~K}_{\mathrm{i}}$ & $\mathrm{a}$ & $3.8 \pm 0.3$ \\
Brilliant Blue FCF & $\mathrm{IC}_{50}$ & $\mathrm{a}$ & $18.4 \pm 2.6$ \\
& $\mathrm{~K}_{\mathrm{i}}$ & $\mathrm{a}$ & $17.7 \pm 2.5$ \\
& & & \\
Carmoisine & $\mathrm{IC}_{50}$ & $9.7 \pm 2.6$ & $2.9 \pm 0.3$ \\
& $\mathrm{~K}_{\mathrm{i}}$ & $7.0 \pm 1.9^{*}$ & $2.7 \pm 0.3 *$ \\
Curcumin & $\mathrm{IC}_{50}$ & $6.9 \pm 1.0$ & $5.4 \pm 1.0$ \\
& $\mathrm{~K}_{\mathrm{i}}$ & $5.0 \pm 0.7$ & $5.3 \pm 1.0$ \\
Neohesperidin DC & $\mathrm{IC}_{50}$ & $48.6 \pm 17.4$ & $15.5 \pm 1.6$ \\
& $\mathrm{~K}_{\mathrm{i}}$ & $35.4 \pm 12.7$ & $14.9 \pm 1.5$ \\
& & & \\
Sunset Yellow FCF & $\mathrm{IC}_{50}$ & $\mathrm{a}$ & $20.3 \pm 1.0$ \\
& $\mathrm{~K}_{\mathrm{i}}$ & $\mathrm{a}$ & $19.6 \pm 1.0$ \\
\hline
\end{tabular}

${ }^{\mathrm{a}} \mathrm{IC}_{50}$ is above $50 \mu \mathrm{M}$ according to the single inhibitor concentration assay and, therefore, $\mathrm{IC}_{50}\left(\mathrm{and}_{\mathrm{i}}\right)$ was not determined $* \mathrm{p}<0.05$, significant difference between $\mathrm{K}_{\mathrm{i}}$ values at $\mathrm{pH} 7.4$ and $\mathrm{pH} 5.5$ 
To evaluate whether the difference in OATP2B1 inhibitory activity at pH 7.4 and $\mathrm{pH} 5.5$ observed for Brilliant Black BN, Brilliant Blue FCF and Sunset Yellow FCF was due to the different extracellular $\mathrm{pH}$ or different substrate used, we tested their OATP2B1 inhibition of estrone sulfate transport also at $\mathrm{pH} 7.4$ at $50 \mu \mathrm{M}$ concentration (Figure 4). Brilliant Black BN displayed $\mathrm{pH}$-dependent activity as no inhibition was observed at $\mathrm{pH}$ 7.4 regardless of the substrate. Brilliant Blue FCF demonstrated $\geq 50 \%$ transport inhibition only at $\mathrm{pH} 5.5$, but decrease in transport function was observed also at $\mathrm{pH} 7.4$ for both substrates. The inhibitory activity of Sunset Yellow FCF seemed to be mostly substrate-dependent since inhibition of estrone sulfate at $\mathrm{pH} 7.4$ and $\mathrm{pH} 5.5$ were comparable but differed from DBF uptake inhibition at $\mathrm{pH} 7.4(\mathrm{p}<0.05)$.

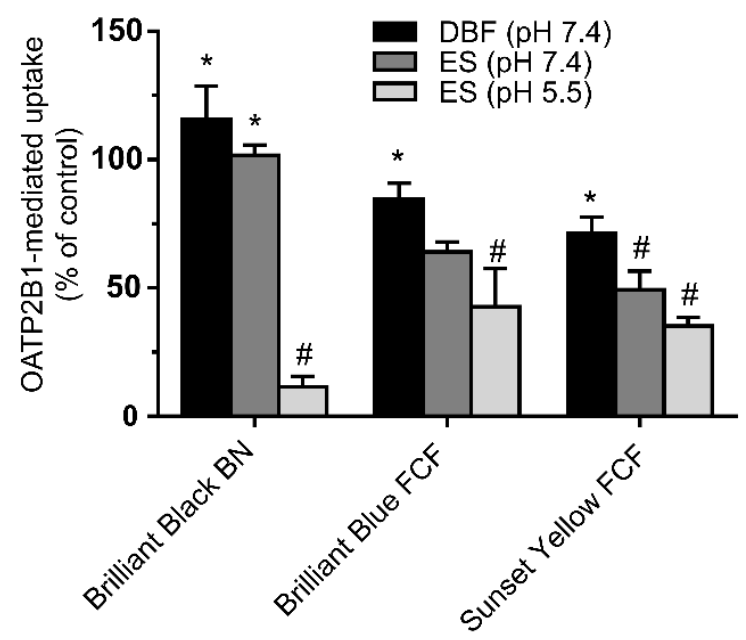

Figure 4. Substrate- and pH-dependent inhibition of OATP2B1-mediated uptake of dibromofluorescein (DBF; 1 $\mu \mathrm{M})$ at $\mathrm{pH} 7.4$, and estrone sulfate $(\mathrm{ES} ; 0.5 \mu \mathrm{M})$ at $\mathrm{pH} 7.4$ and $\mathrm{pH} 5.5$ by selected food additives. Concentration of food additive was $50 \mu \mathrm{M}(40 \mu \mathrm{M}$ for Brilliant Black inhibition of estrone sulfate transport). Results are expressed as mean \pm SD from one study with three replicates except for estrone sulfate ( $\mathrm{pH}$ 5.5), where results are expressed as mean \pm SD from three independent studies with three replicates. Data was partly integrated from inhibitor identification assays (Figure 2) and dose-response studies (Figure 3). *p < 0.05 compared to ES (pH 5.5), \#p $<0.05$ compared to DBF (pH 7.4). 
To rule out false positive or negative results due to fluorescence interference of test compounds or poor aqueous solubility of food additives, assay interference studies were performed. Quenching of DBF fluorescence signal was observed for nine compounds when DBF fluorescence was measured together with $50 \mu \mathrm{M}$ food additive (Supporting Information Figure S2). Four of these compounds (Allura Red AC, Carmoisine, curcumin and rebaudioside A) were identified as OATP2B1 inhibitors at pH 7.4 in the initial inhibition assay. However, as it is very unlikely that all of the food additive is taken up into the cells during the uptake assay, the fluorescence interference was then tested with lower concentrations for these four compounds. When it was assumed that $10 \%$ $(5 \mu \mathrm{M})$ or less of the food additive is retained in the final sample elute in the uptake assay, quenching of DBF fluorescence was less than $10 \%$ for all four compounds (Figure 5A).

The solubility of the food additives in transport buffer was tested to rule out OATP2B1 inhibition by aggregates. Only curcumin displayed clear aggregation at the $50 \mu \mathrm{M}$ test concentration at $\mathrm{pH} 7.4$ and $\mathrm{pH} 5.5$ and was subjected to further studies (Figure 5B; Supporting Information Figure S3). At both $\mathrm{pH}$ conditions, curcumin had a similar solubility profile, with significant aggregation observed at concentrations over $1 \mu \mathrm{M}(\mathrm{p}<0.05)$.

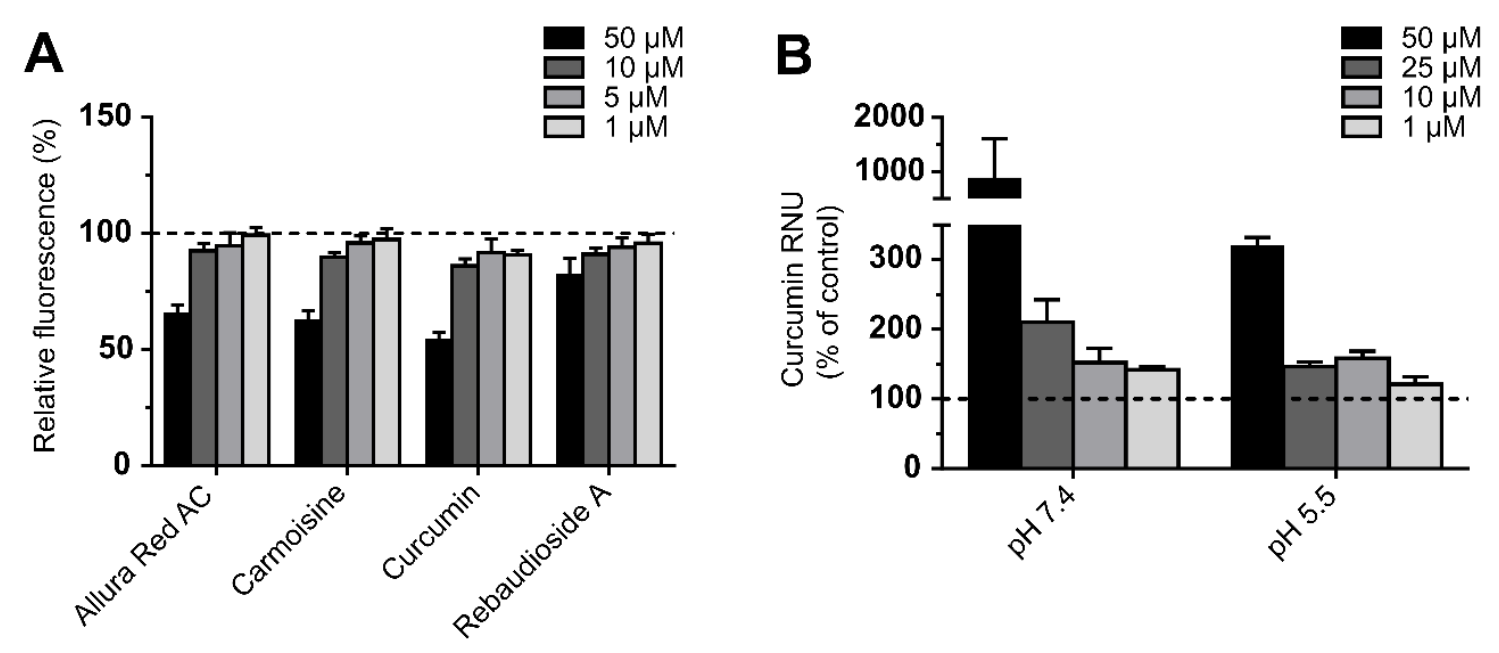

Figure 5. A) Fluorescence interference of selected food additives with $0.1 \mu \mathrm{M}$ dibromofluorescein (DBF) assuming that $100 \%(50 \mu \mathrm{M}), 20 \%(10 \mu \mathrm{M}), 10 \%(5 \mu \mathrm{M})$ or $2 \%(1 \mu \mathrm{M})$ of the initial food additive in the HEK293 uptake assay would be retained in final samples. Results are expressed as relative fluorescence of $0.1 \mu \mathrm{M} \mathrm{DBF}$ with food additive compared to DBF fluorescence alone. B) Solubility of curcumin in transport buffer (pH 7.4 and $\mathrm{pH}$ 5.5) measured with nephelometry. Results are expressed as mean \pm SD (three replicates) relative nephelometric unit (RNU) of curcumin in transport buffer normalized to RNU of transport buffer alone. 


\section{DISCUSSION}

In this study, we identified seven food additives as OATP2B1 inhibitors from a selection of 25 commonly used colorants, preservatives and sweeteners. With the exception of the sweetener neohesperidin DC, all OATP2B1 inhibitors were color additives. Moreover, the inhibitors were mostly azo dyes as Allura Red AC, Brilliant Black BN, Carmoisine and Sunset Yellow FCF share the functional group diazenyl R-N=N-R' (Supporting Information Figure S4). In general, high molecular weight and, conversely, both lipophilicity and polarity are characteristic for OATP inhibitors. ${ }^{29}$ Among the studied food additives, most OATP2B1 inhibitors were rather polar and of high molecular weight, as they had calculated $\log \mathrm{D}_{7.4}$ and $\log \mathrm{D}_{5.5}$ between -7.64 to -0.17 and molecular weights above $350 \mathrm{Da}$ (Supporting Information Table S3). The calculated $\log \mathrm{D}_{7.4}$ and $\log \mathrm{D}_{5.5}$ of neohesperidin DC and curcumin were higher, ranging from 2.59 to 3.08. Assay interference studies indicated that curcumin inhibitor properties could have been affected by aggregates in the test solution. However, clear curcumin dose-dependent inhibition of OATP2B1 was observed notwithstanding the inhibition mechanism by curcumin specifically or its aggregates. Our findings regarding the inhibitory potential of curcumin are also in agreement with a previous study where 10 $\mu \mathrm{M}$ curcumin significantly inhibited OATP2B1-mediated transport of estrone sulfate at $\mathrm{pH} 7.4{ }^{30}$

During the review process of this manuscript, a study investigating food and drug additives as OATP2B1 inhibitors was published. ${ }^{31}$ Similar to our study, OATP2B1 inhibitors identified in this study were mostly color additives and, furthermore, enriched in azo dyes. When DBF was used as substrate, comparable $\mathrm{K}_{\mathrm{i}}$ values were obtained for Allura Red AC and neohesperidin DC in both studies, and the $\mathrm{K}_{\mathrm{i}}$ value of Sunset Yellow FCF $(68.4 \mu \mathrm{M})$ is also in agreement with our screening result with $\mathrm{DBF}$ at $\mathrm{pH}$ 7.4. However, we defined lower $\mathrm{K}_{\mathrm{i}}$ values for Allura Red AC $\left(1.5 \mu \mathrm{M}\right.$ versus $\left.10.5 \mu \mathrm{M}^{31}\right)$ and Sunset Yellow FCF $\left(19.6 \mu \mathrm{M}\right.$ versus $\left.54.2 \mu \mathrm{M}^{31}\right)$ when estrone sulfate was used as substrate, which is possibly explained by our acidic assay condition compared to neutral pH used by Zou et al. ${ }^{31}$ We did not observe significant OATP2B1 inhibition of DBF uptake by $50 \mu \mathrm{M}$ Brilliant Blue FCF (uptake $84.7 \%$ of control), but Zou et al. ${ }^{31}$ reported marked decrease of DBF transport by $200 \mu \mathrm{M}$ Brilliant Blue FCF and defined a $\mathrm{K}_{\mathrm{i}}$ value of $13.0 \mu \mathrm{M}$, which is comparable with the $\mathrm{K}_{\mathrm{i}}$ value we obtained for estrone sulfate at $\mathrm{pH}$ 5.5. We used only a single concentration $(50 \mu \mathrm{M})$ in the initial inhibitor identification assay, and advanced food additives inhibiting OATP2B1 transport $\geq 50 \%$ for dose-response studies, which could have underestimated the prevalence of relevant inhibitors among food additives that are present in high amounts in food products. However, ten of the inactive food additives in our study were included in the study by Zou et al., ${ }^{31}$ and were not identified as OATP2B1 inhibitors even though Zou et al. used mostly higher concentrations $(200-1000 \mu \mathrm{M})$ for the initial single concentration inhibitor screen. Comparison of these results from our study and the study by Zou et al. ${ }^{31}$ are summarized in Supporting Information Table S4.

The function of OATP2B1 is known to be largely substrate- and perpetrator-dependent, a phenomenon explained at least partly by multiple binding sites on OATP2B1 and best described for estrone sulfate transport. ${ }^{21,25}$ OATP2B1 has low- and high affinity sites for estrone sulfate, which, however, are not necessarily completely common with binding sites for other substrates. ${ }^{25}$ Also perpetrators may alter the function of either the low- or high-affinity site or both, and yet the possibility of allosteric binding sites cannot be excluded. ${ }^{25,32,33}$ Furthermore, perpetrators can either stimulate or inhibit these binding sites independently, as progesterone stimulates the uptake of estrone sulfate by the high-affinity site but rather inhibits the low-affinity site. ${ }^{25}$ In addition to significant OATP2B1 inhibition by food additives, we observed an apparent OATP2B1 stimulating effect for sucralose, which increased OATP2B1 mediated uptake of DBF with $\geq 50 \%$ at $\mathrm{pH} 7.4$ but not uptake of estrone sulfate at $\mathrm{pH} 5.5$. These findings may be an artifact of screening with a single concentration, as Zou et al. ${ }^{31}$ did not observe any effect on OATP2B1-mediated transport of DBF with $1000 \mu \mathrm{M}$ sucralose. However, due to the complicated nature of OATP2B1 modulation described above, the stimulation of OATP2B1 by sucralose could be substrate- and also concentration-dependent similar to progesterone, which stimulates OATP2B1 at lower concentrations but the 
stimulatory effect fades out with higher concentrations. ${ }^{32}$ The apparent stimulatory effect of food additives require further experiments dedicated for this purpose, as well as studies addressing the overall clinical relevance of OATP2B1 stimulation, which is currently lacking. ${ }^{33,34}$

OATP2B1 has maximal functional activity at an acidic extracellular environment, ${ }^{20,26}$ which can be relevant in the intestine, where orally administered drugs are exposed to a $\mathrm{pH}$ gradient. Therefore, the International Transporter Consortium has suggested that incorporation of acidic assay conditions to standard OATP2B1 in vitro studies at neutral $\mathrm{pH}$ could improve translation of in vitro results to the clinical situation. ${ }^{19}$ The luminal $\mathrm{pH}$ can vary from about 4.5 to 8.0 in different intestinal segments, but the $\mathrm{pH}$-microclimate at the epithelial cell surface is typically between 5.2 and $6.7 .{ }^{35,36}$ Considering the $\mathrm{pH}$ - and substrate-dependent function of OATP2B1, we included studies with estrone sulfate at $\mathrm{pH} 5.5$ to accompany findings from neutral assay conditions with DBF, and identified three colorants that inhibited OATP2B1 at $\mathrm{pH} 5.5$ but not at $\mathrm{pH}$ 7.4. However, as these observations could be due to change in extracellular $\mathrm{pH}$ and/or different substrates between the two conditions, we then tested the inhibition of estrone sulfate also at $\mathrm{pH} 7.4$ for the three additives that were identified as inhibitors of estrone sulfate transport at $\mathrm{pH} 5.5$ but not DBF at pH 7.4 (Figure 4). An apparent pH-dependent inhibitory effect of Brilliant Black BN was observed as no inhibition was evident at $\mathrm{pH} 7.4$ regardless of the substrate, but the inhibitor activity of Brilliant Blue FCF and Sunset Yellow FC was more diverse. These findings could be explained by the multiple binding sites on OATP2B1 as only the low affinity estrone sulfate binding site shows $\mathrm{pH}$-dependent substrate transport. ${ }^{21}$ The effect of extracellular $\mathrm{pH}$ on OATP2B1 inhibitor activity has not been comprehensively studied. Varma et al. ${ }^{20}$ studied the inhibitor properties of rifamycin SV on OATP2B1-mediated uptake of estrone sulfate and rosuvastatin and observed similar profiles at $\mathrm{pH} 7.4$ and $\mathrm{pH}$ 6.0. Our results suggest that OATP2B1-inhibition is $\mathrm{pH}-$, substrate- and perpetrator-dependent, which complicates the extrapolation of results from one substrate and perpetrator to another and that care should be taken also to choose in vitro assay conditions carefully to imitate the in vivo site of inhibition.

Although systemic absorption of especially many colorants is negligible, ${ }^{1}$ concentrations in the intraluminal space of the GI tract can be high due to high amounts of additives in food and beverage. For example, detected concentrations of Allura Red AC in drinks and juices can vary from 0.1 to over $2000 \mathrm{mg} / \mathrm{kg}$. ${ }^{5}$ According to European Medicines Agency (EMA) guidance on drug interactions, in vivo inhibition of intestinal transporters cannot be ruled out if observed $\mathrm{K}_{\mathrm{i}}$ values are lower than maximum expected concentration in the intestinal lumen, which is defined as 0.1 -fold the maximum dose on one occasion $/ 250 \mathrm{ml} .{ }^{37}$ However, the maximum single doses of food additives are difficult to estimate, because additive amounts in food can vary from product to product, consumption patterns are individual, and the daily additive intake is not typically ingested as a single bolus. To evaluate the possibility of in vivo inhibition of OATP2B1 by selected food additives, we decided to use EFSA estimates of maximum daily dietary exposure for a high-level consumer (if available) as the maximum food additive dose (Table 2). Of the OATP2B1 inhibitors identified, neohesperidin DC was the only additive where in vivo inhibition could be ruled out based on these calculations. For all other food additives, the resulting intestinal threshold concentrations for in vivo inhibition (0.1-fold the maximum dose/250 ml) are higher than the defined $\mathrm{K}_{\mathrm{i}}$ values. For example, the concentrations calculated for Allura Red AC are 113-fold and 45-fold higher than the $\mathrm{K}_{\mathrm{i}}$ values obtained at $\mathrm{pH} 7.4$ (DBF) and $\mathrm{pH} 5.5$ (estrone sulfate). 
Table 2. Estimated dietary exposure and estimation of intestinal concentrations [I] of selected food additives.

\begin{tabular}{|c|c|c|c|}
\hline \multirow{2}{*}{ Food additive } & \multicolumn{2}{|c|}{$\begin{array}{l}\text { Dietary exposure }{ }^{\mathrm{a}} \\
\text { (mg/kg bw/day) }\end{array}$} & \multirow[t]{2}{*}{$\begin{array}{l}{\left[\mathrm{II}^{\mathrm{c}}\right.} \\
(\mu \mathrm{M})\end{array}$} \\
\hline & Mean & $\begin{array}{c}\text { High } \\
\text { level }^{\mathrm{b}}\end{array}$ & \\
\hline $\begin{array}{l}\text { Allura Red AC } \\
\mathrm{K}_{\mathrm{i}}(\mathrm{pH} 7.4)=0.6 \mu \mathrm{M} \\
\mathrm{K}_{\mathrm{i}}(\mathrm{pH} 5.5)=1.5 \mu \mathrm{M}\end{array}$ & $0.1-0.4$ & $0.4-1.2$ & 68 \\
\hline Brilliant Black BN & & & \\
\hline $\mathrm{K}_{\mathrm{i}}(\mathrm{pH} 5.5)=3.8 \mu \mathrm{M}$ & $0.05-0.30$ & $0.23-0.69$ & 22 \\
\hline $\begin{array}{l}\text { Brilliant Blue FCF } \\
\mathrm{K}_{\mathrm{i}}(\mathrm{pH} 5.5)=17.7 \mu \mathrm{M}\end{array}$ & 0.6 & 3.0 & 106 \\
\hline $\begin{array}{l}\text { Carmoisine } \\
\mathrm{K}_{\mathrm{i}}(\mathrm{pH} \text { 7.4) }=7.0 \mu \mathrm{M} \\
\mathrm{K}_{\mathrm{i}}(\mathrm{pH} \text { 5.5) }=2.7 \mu \mathrm{M}\end{array}$ & $0.04-0.3$ & $0.2-0.9$ & 50 \\
\hline $\begin{array}{l}\text { Curcumin } \\
\mathrm{K}_{\mathrm{i}}(\mathrm{pH} 7.4)=5.0 \mu \mathrm{M} \\
\mathrm{K}_{\mathrm{i}}(\mathrm{pH} \text { 5.5) }=5.3 \mu \mathrm{M}\end{array}$ & $0.2-0.6$ & $0.4-1.5$ & 114 \\
\hline $\begin{array}{l}\text { Neohesperidin DC } \\
\mathrm{K}_{\mathrm{i}}(\mathrm{pH} 7.4)=35.4 \mu \mathrm{M} \\
\mathrm{K}_{\mathrm{i}}(\mathrm{pH} 5.5)=14.9 \mu \mathrm{M}\end{array}$ & $0.02^{\mathrm{d}}$ & - & 1 \\
\hline $\begin{array}{l}\text { Sunset Yellow FCF } \\
\mathrm{K}_{\mathrm{i}}(\mathrm{pH} 5.5)=19.6 \mu \mathrm{M}\end{array}$ & $0.01-0.1$ & $0.1-0.4$ & 25 \\
\hline
\end{tabular}

\footnotetext{
${ }^{a}$ Data from EFSA (European Food Safety Authority) exposure assessments (References ${ }^{38-44}$ ). Data for maximum reported use level or brand-loyal scenario in adults, if not otherwise stated

b $95^{\text {th }}$ or 97 th percentile

${ }^{c}$ [I] Estimated intestinal concentration calculated according to EMA guidance (0.1-fold the maximum dose on one occasion/250 $\left.\mathrm{ml}\right) .{ }^{37} \mathrm{The}$ daily dietary exposure (maximum for high-level consumer, if available) for a $70 \mathrm{~kg}$ person was used as the maximum dose

${ }^{\mathrm{d}}$ Calculated from modified theoretical added maximum daily intake
}

Based on the relationships between $\mathrm{K}_{\mathrm{i}}$ values and intestinal exposure to food additives, in vivo studies would be justified to elucidate the impact of OATP2B1 inhibition by selected food additives. ${ }^{37}$ Considering that OATP2B1 is the main OATP isoform in the intestine and it transports a broad range of drugs, in vivo inhibition of OATP2B1 would be expected to alter the intestinal absorption of OATP2B1 substrate drugs given that OATP2B1 is a major contributor to absorption of the substrate. It would not be unforeseen if food additives would cause clinical drug interactions via OATP2B1 inhibition, as dietary and natural products, especially fruit juices, have shown to decrease the exposure of OATP2B1 substrate drugs. ${ }^{13}$ On the other hand, the lack of clinical OATP2B1-mediated drug-drug interactions can be considered rather surprising, as in vitro OATP2B1 inhibitors are not particularly rare among clinically used drugs. ${ }^{28}$ The reason could be that OATP2B1 is not the predominant mechanism in drug absorption in vivo as other contributing pathways may exist. Other reasons could be that OATP2B1 has been understudied and more clinical interactions appear when systematic research becomes common. As we demonstrated here, more OATP2B1 inhibitors were identified at acidic assay conditions, suggesting that potential intestinal OATP2B1 inhibitors could be overlooked if studied only at neutral $\mathrm{pH}$ 7.4.

As we have previously demonstrated, food additives can inhibit other intestinal transporters as well..$^{5}$ All food additives identified as OATP2B1 inhibitors in this study have been previously identified also as BCRP and/or MRP2 inhibitors. ${ }^{5,6}$ Considering that the consequences of intestinal apical efflux transporter inhibition are opposite to the effects of OATP2B1 uptake inhibition, the concurrent inhibition of both transporters could overrule the 
estimated clinical effects for individual transporters taken that the substrate is also transported by both transporters. For example, curcumin can inhibit many intestinal drug transporters relevant for drug absorption (OATP2B1, BCRP, MRP2 and P-gp) as well as drug metabolizing enzymes in vitro, ${ }^{5,45}$ making extrapolation of in vivo effects complicated based on separate in vitro assays. However, inhibition of efflux transporters and drug metabolizing enzymes require inhibitor access to the transporter from intracellular side, which may not be achievable for food additives with limited absorption. Food additives can also be extensively metabolized during GI transit. For example, azo dyes are susceptible to bacterial azo reduction, ${ }^{46}$ and sweeteners neohesperidin DC, stevioside and rebaudioside A to bacterial deglycosylation. ${ }^{47,48}$ Notably, Zou et al. ${ }^{31}$ demonstrated that the reduced metabolites of azo dyes did not inhibit OATP2B1 in vitro, and that high $(25 \mathrm{mg} / \mathrm{kg})$ but not low $(2.5 \mathrm{mg} / \mathrm{kg})$ dose Allura Red $\mathrm{AC}$ decreased the exposure of fexofenadine in P-gp-deficient $(\mathrm{mdrla} / \mathrm{b}-/-)$ mice. These results suggest that high doses of azo dyes have the potential to saturate the azoreductase capacity of the gut microbiome, which then can result in intact dye concentrations high enough to cause observable intestinal OATP2B1 inhibition. ${ }^{31}$

In conclusion, this study demonstrates that in addition to previously recognized inhibitory effects on ABC-efflux transporters, ${ }^{5,6}$ commonly used food additives can inhibit the intestinal uptake transporter OATP2B1 in vitro. Out of the 25 tested food additives, six colorants and one sweetener were validated as OATP2B1 inhibitors. Several colorants were found to inhibit OATP2B1 with inhibitory constants well below estimated intestinal food additive concentrations. We also demonstrated substrate- and pH-dependent inhibition of OATP2B1, as more inhibitors were identified when estrone sulfate was used as OATP2B1 substrate at $\mathrm{pH} 5.5$ mimicking the acidic intestinal environment. Altogether, the results of this study suggest that high exposure to food additives could cause interindividual variability on the absorption of orally administered drugs, but considering the complexity of OATP2B1 modulation, further studies evaluating the overall in vivo effect of food additive-drug interactions are required. 


\section{ACKNOWLEDGEMENTS}

We would like to thank Timo Oksanen and Leena Pietilä for technical assistance, and Wilma Kiander and Noora Sjöstedt for their advice in conducting the research. The Drug Discovery and Chemical Biology Network, funded by Biocenter Finland, is acknowledged for providing access to the screening instrumentation.

Funding: This work was supported, in part, by Swedish Cultural Foundation in Finland, Magnus Ehrnrooth Foundation and Finnish Cultural Foundation.

\section{SUPPORTING INFORMATION}

Figure S1: Time-dependent uptake of DBF and estrone sulfate

Tables S1 and S2: Data used to analyze concentration-dependent uptake of DBF and estronesulfate

Figure S2: DBF fluorescence interference with food additives $(50 \mu \mathrm{M})$

Figure S3: Solubility of food additives $(50 \mu \mathrm{M})$ in transport buffer

Figure S4: Structural formulas of the food additives that were identified as OATP2B1 inhibitors

Table S3: Molecular properties of the tested food additives

Table S4: Inhibition of OATP2B1-mediated uptake by food additives $(50 \mu \mathrm{M})$ and comparison with results from study by Zou et al. ${ }^{31}$ 


\section{REFERENCES}

(1) Amchova, P.; Kotolova, H.; Ruda-Kucerova, J. Health Safety Issues of Synthetic Food Colorants. Regul. Toxicol. Pharmacol. 2015, 73 (3), 914-922.

(2) Koziolek, M.; Alcaro, S.; Augustijns, P.; Basit, A. W.; Grimm, M.; Hens, B.; Hoad, C. L.; Jedamzik, P.; Madla, C. M.; Maliepaard, M.; Marciani, L.; Maruca, A.; Parrott, N.; Pávek, P.; Porter, C. J. H.; Reppas, C.; van Riet-Nales, D.; Rubbens, J.; Statelova, M.; Trevaskis, N. L.; Valentová, K.; Vertzoni, M.; Čepo, D. V.; Corsetti, M. The Mechanisms of Pharmacokinetic Food-Drug Interactions - A Perspective from the UNGAP Group. Eur. J. Pharm. Sci. 2019, 134, 31-59.

(3) Zhang, W.; Li, Y.; Zou, P.; Wu, M.; Zhang, Z.; Zhang, T. The Effects of Pharmaceutical Excipients on Gastrointestinal Tract Metabolic Enzymes and Transporters-an Update. AAPS J. 2016, 18 (4), 830-843.

(4) Al-Ali, A. A. A.; Nielsen, R. B.; Steffansen, B.; Holm, R.; Nielsen, C. U. Nonionic Surfactants Modulate the Transport Activity of ATP-Binding Cassette (ABC) Transporters and Solute Carriers (SLC): Relevance to Oral Drug Absorption. Int. J. Pharm. 2019, 566, 410-433.

(5) Sjöstedt, N.; Deng, F.; Rauvala, O.; Tepponen, T.; Kidron, H. Interaction of Food Additives with Intestinal Efflux Transporters. Mol. Pharmaceutics 2017, 14 (11), 3824-3833.

(6) Zou, L.; Pottel, J.; Khuri, N.; Ngo, H. X.; Ni, Z.; Tsakalozou, E.; Warren, M. S.; Huang, Y.; Shoichet, B. K.; Giacomini, K. M. Interactions of Oral Molecular Excipients with Breast Cancer Resistance Protein, BCRP. Mol. Pharmaceutics 2020, 17 (3), 748-756.

(7) Engel, A.; Oswald, S.; Siegmund, W.; Keiser, M. Pharmaceutical Excipients Influence the Function of Human Uptake Transporting Proteins. Mol. Pharmaceutics 2012, 9 (9), 2577-2581.

(8) Otter, M.; Oswald, S.; Siegmund, W.; Keiser, M. Effects of Frequently Used Pharmaceutical Excipients on the Organic Cation Transporters 1-3 and Peptide Transporters 1/2 Stably Expressed in MDCKII Cells. Eur. J. Pharm. Biopharm. 2017, 112, 187-195.

(9) Drozdzik, M.; Gröer, C.; Penski, J.; Lapczuk, J.; Ostrowski, M.; Lai, Y.; Prasad, B.; Unadkat, J. D.; Siegmund, W.; Oswald, S. Protein Abundance of Clinically Relevant Multidrug Transporters along the Entire Length of the Human Intestine. Mol. Pharmaceutics 2014, 11 (10), 3547-3555.

(10) McFeely, S. J.; Wu, L.; Ritchie, T. K.; Unadkat, J. Organic Anion Transporting Polypeptide 2B1 - More than a Glass-Full of Drug Interactions. Pharmacol. Ther. 2019, 196, 204-215.

(11) Keiser, M.; Kaltheuner, L.; Wildberg, C.; Müller, J.; Grube, M.; Partecke, L. I.; Heidecke, C. D.; Oswald, S. The Organic Anion-Transporting Peptide 2B1 Is Localized in the Basolateral Membrane of the Human Jejunum and Caco-2 Monolayers. J. Pharm. Sci. 2017, 106 (9), 2657-2663.

(12) Kobayashi, D.; Nozawa, T.; Imai, K.; Nezu, J.; Tsuji, A.; Tamai, I. Involvement of Human Organic Anion Transporting Polypeptide OATP-B (SLC21A9) in pH-Dependent Transport across Intestinal Apical Membrane. J. Pharmacol. Exp. Ther. 2003, 306 (2), 703-708.

(13) Yu, J.; Zhou, Z.; Tay-Sontheimer, J.; Levy, R. H.; Ragueneau-Majlessi, I. Intestinal Drug Interactions Mediated by OATPs: A Systematic Review of Preclinical and Clinical Findings. J. Pharm. Sci. 2017, 106 (9), 2312-2325. 
(14) Ieiri, I.; Doi, Y.; Maeda, K.; Sasaki, T.; Kimura, M.; Hirota, T.; Chiyoda, T.; Miyagawa, M.; Irie, S.; Iwasaki, K.; Sugiyama, Y. Microdosing Clinical Study: Pharmacokinetic, Pharmacogenomic (SLCO2B1), and Interaction (Grapefruit Juice) Profiles of Celiprolol Following the Oral Microdose and Therapeutic Dose. J. Clin. Pharmacol. 2012, 52 (7), 1078-1089.

(15) Imanaga, J.; Kotegawa, T.; Imai, H.; Tsutsumi, K.; Yoshizato, T.; Ohyama, T.; Shirasaka, Y.; Tamai, I.; Tateishi, T.; Ohashi, K. The Effects of the SLCO2B1 c.1457C>T Polymorphism and Apple Juice on the Pharmacokinetics of Fexofenadine and Midazolam in Humans. Pharmacogenet. Genomics 2011, 21 (2), 84-93.

(16) Tapaninen, T.; Neuvonen, P. J.; Niemi, M. Orange and Apple Juice Greatly Reduce the Plasma Concentrations of the OATP2B1 Substrate Aliskiren. Br. J. Clin. Pharmacol. 2011, 71 (5), 718-726.

(17) Chen, M.; Hu, S.; Li, Y.; Gibson, A. A.; Fu, Q.; Baker, S. D.; Sparreboom, A. Role of Oatp2b1 in Drug Absorption and Drug-Drug Interactions. Drug Metab. Dispos. 2020, 48 (5), 419-425.

(18) Medwid, S.; Li, M. M. J.; Knauer, M. J.; Lin, K.; Mansell, S. E.; Schmerk, C. L.; Zhu, C.; Griffin, K. E.; Yousif, M. D.; Dresser, G. K.; Schwarz, U. I.; Kim, R. B.; Tirona, R. G. Fexofenadine and Rosuvastatin Pharmacokinetics in Mice with Targeted Disruption of Organic Anion Transporting Polypeptide 2B1. Drug Metab. Dispos. 2019, 47 (8), 832-842.

(19) Zamek-Gliszczynski, M. J.; Taub, M. E.; Chothe, P. P.; Chu, X.; Giacomini, K. M.; Kim, R. B.; Ray, A. S.; Stocker, S. L.; Unadkat, J. D.; Wittwer, M. B.; Xia, C.; Yee, S. W.; Zhang, L.; Zhang, Y. Transporters in Drug Development: 2018 ITC Recommendations for Transporters of Emerging Clinical Importance. Clin. Pharmacol. Ther. 2018, 104 (5), 890-899.

(20) Varma, M. V.; Rotter, C. J.; Chupka, J.; Whalen, K. M.; Duignan, D. B.; Feng, B.; Litchfield, J.; Goosen, T. C.; El-Kattan, A. F. pH-Sensitive Interaction of HMG-CoA Reductase Inhibitors (Statins) with Organic Anion Transporting Polypeptide 2B1. Mol. Pharmaceutics 2011, 8 (4), 1303-1313.

(21) Shirasaka, Y.; Mori, T.; Shichiri, M.; Nakanishi, T.; Tamai, I. Functional Pleiotropy of Organic Anion Transporting Polypeptide OATP2B1 Due to Multiple Binding Sites. Drug Metab. Pharmacokinet. 2012, 27 (3), 360-364.

(22) Sjöstedt, N.; van den Heuvel, J. J. M. W.; Koenderink, J. B.; Kidron, H. Transmembrane Domain SingleNucleotide Polymorphisms Impair Expression and Transport Activity of ABC Transporter ABCG2. Pharm. Res. 2017, 34 (8), 1626-1636.

(23) Cheng,Y.; Prusoff, W. H. Relationship between the Inhibition Constant (KI) and the Concentration of Inhibitor Which Causes 50 per Cent Inhibition (I50) of an Enzymatic Reaction. Biochem. Pharmacol. 1973, 22 (23), 3099-3108.

(24) Brouwer, K. L. R.; Keppler, D.; Hoffmaster, K. A.; Bow, D. a. J.; Cheng, Y.; Lai, Y.; Palm, J. E.; Stieger, B.; Evers, R. In Vitro Methods to Support Transporter Evaluation in Drug Discovery and Development. Clin. Pharmacol. Ther. 2013, 94 (1), 95-112.

(25) Hoshino, Y.; Fujita, D.; Nakanishi, T.; Tamai, I. Molecular Localization and Characterization of Multiple Binding Sites of Organic Anion Transporting Polypeptide 2B1 (OATP2B1) as the Mechanism for Substrate and Modulator Dependent Drug-Drug Interaction. MedChemComm 2016, 7 (9), 1775-1782. 
(26) Nozawa, T.; Imai, K.; Nezu, J. I.; Tsuji, A.; Tamai, I. Functional Characterization of pH-Sensitive Organic Anion Transporting Polypeptide OATP-B in Human. J. Pharmacol. Exp. Ther. 2004, 308 (2), 438-445.

(27) Izumi, S.; Nozaki, Y.; Komori, T.; Takenaka, O.; Maeda, K.; Kusuhara, H.; Sugiyama, Y. Investigation of Fluorescein Derivatives as Substrates of Organic Anion Transporting Polypeptide (OATP) 1B1 To Develop Sensitive Fluorescence-Based OATP1B1 Inhibition Assays. Mol. Pharmaceutics 2016, 13 (2), 438-448.

(28) Unger, M. S.; Mudunuru, J.; Schwab, M.; Hopf, C.; Drewes, G.; Nies, A. T.; Zamek-Gliszczynski, M. J.; Reinhard, F. B. M. Clinically Relevant OATP2B1 Inhibitors in Marketed Drug Space. Mol. Pharmaceutics. 2020, 17 (2), 488-498.

(29) Karlgren, M.; Vildhede, A.; Norinder, U.; Wisniewski, J. R.; Kimoto, E.; Lai, Y.; Haglund, U.; Artursson, P. Classification of Inhibitors of Hepatic Organic Anion Transporting Polypeptides (OATPs): Influence of Protein Expression on Drug-Drug Interactions. J. Med. Chem. 2012, 55 (10), 4740-4763.

(30) Kondo, A.; Narumi, K.; Ogura, J.; Sasaki, A.; Yabe, K.; Kobayashi, T.; Furugen, A.; Kobayashi, M.; Iseki, K. Organic Anion-Transporting Polypeptide (OATP) 2B1 Contributes to the Cellular Uptake of Theaflavin. Drug Metab. Pharmacokinet. 2017, 32 (2), 145-150.

(31) Zou, L.; Spanogiannopoulos, P.; Pieper, L. M.; Chien, H.-C.; Cai, W.; Khuri, N.; Pottel, J.; Vora, B.; Ni, Z.; Tsakalozou, E.; Zhang, W.; Shoichet, B. K.; Giacomini, K. M.; Turnbaugh, P. J. Bacterial Metabolism Rescues the Inhibition of Intestinal Drug Absorption by Food and Drug Additives. Proc. Natl. Acad. Sci. U. S. A. 2020, 117 (27), 16009-16018.

(32) Grube, M.; Köck, K.; Karner, S.; Reuther, S.; Ritter, C. A.; Jedlitschky, G.; Kroemer, H. K. Modification of OATP2B1-Mediated Transport by Steroid Hormones. Mol. Pharmacol. 2006, 70 (5), 1735-1741.

(33) Ogura, J.; Yamaguchi, H.; Mano, N. Stimulatory Effect on the Transport Mediated by Organic Anion Transporting Polypeptide 2B1. Asian J. Pharm. Sci. 2020, 15 (2), 181-191.

(34) Rodrigues, A. D.; Lai, Y.; Shen, H.; Varma, M. V. S.; Rowland, A.; Oswald, S. Induction of Human Intestinal and Hepatic Organic Anion Transporting Polypeptides: Where Is the Evidence for Its Relevance in Drug-Drug Interactions? Drug Metab. Dispos. 2020, 48 (3), 205-216.

(35) Shiau, Y. F.; Fernandez, P.; Jackson, M. J.; McMonagle, S. Mechanisms Maintaining a Low-pH Microclimate in the Intestine. Am. J. Physiol.: Gastrointest. Liver Physiol. 1985, 248 (6), G608-G617.

(36) Avdeef, A. Physicochemical Profiling (Solubility, Permeability and Charge State). Curr. Top. Med. Chem. 2001, 1 (4), 277-351.

(37) Guideline on the Investigation of Drug Interactions; CPMP/EWP/560/95/Rev. 1 Corr. 2**; Committee for Human Medicinal Products (CHMP), European Medicines Agency: London, United Kingdom, 2012.

(38) European Food Safety Authority. Refined Exposure Assessment for Allura Red AC (E 129). EFSA J. 2015, 13 (2), 4007. DOI: 10.2903/j.efsa.2015.4007.

(39) European Food Safety Authority. Refined Exposure Assessment for Brilliant Black BN (E 151). EFSA J. 2015, 13 (1), 3960. DOI:10.2903/j.efsa.2015.3960. 
(40) EFSA Panel on Food Additives and Nutrient Sources added to Food. Scientific Opinion on the ReEvaluation of Brilliant Blue FCF (E 133) as a Food Additive. EFSA J. 2010, 8 (11), 1853. DOI: 10.2903/j.efsa.2010.1853.

(41) European Food Safety Authority. Refined Exposure Assessment for Azorubine/Carmoisine (E 122). EFSA J. 2015, 13 (3), 4072. DOI: 10.2903/j.efsa.2015.4072.

(42) European Food Safety Authority. Refined Exposure Assessment for Curcumin (E 100). EFSA J. 2014, 12 (10), 3876. DOI: 10.2903/j.efsa.2014.3876.

(43) EFSA Panel on Food Contact Materials, Enzymes, Flavourings and Processing Aids. Flavouring Group Evaluation 32 (FGE.32): Flavonoids (Flavanones and Dihydrochalcones) from Chemical Groups 25 and 30. EFSA J. 2010, 8 (9), 1065. DOI: 10.2903/j.efsa.2010.1065.

(44) EFSA Panel on Food Additives and Nutrient Sources added to Food. Reconsideration of the Temporary ADI and Refined Exposure Assessment for Sunset Yellow FCF (E 110). EFSA J. 2014, 12 (7), 3765. DOI: $10.2903 /$ j.efsa.2014.3765.

(45) Bahramsoltani, R.; Rahimi, R.; Farzaei, M. H. Pharmacokinetic Interactions of Curcuminoids with Conventional Drugs: A Review. J. Ethnopharmacol. 2017, 209, 1-12.

(46) Chung, K. T.; Stevens, S. E.; Cerniglia, C. E. The Reduction of Azo Dyes by the Intestinal Microflora. Crit. Rev. Microbiol. 1992, 18 (3), 175-190.

(47) Gardana, C.; Simonetti, P.; Canzi, E.; Zanchi, R.; Pietta, P. Metabolism of Stevioside and Rebaudioside A from Stevia Rebaudiana Extracts by Human Microflora. J. Agric. Food Chem. 2003, 51 (22), 6618-6622.

(48) Braune, A.; Engst, W.; Blaut, M. Degradation of Neohesperidin Dihydrochalcone by Human Intestinal Bacteria. J. Agric. Food Chem. 2005, 53 (5), 1782-1790. 


\title{
FOOD ADDITIVES AS INHIBITORS OF INTESTINAL DRUG TRANSPORTER OATP2B1
}

\author{
Alli Tikkanen ${ }^{1}$, Estelle Pierrot ${ }^{1}$, Feng Deng ${ }^{1,2}$, Virginia Barras Sanchez ${ }^{1}$, Marja Hagström ${ }^{1}$, Jan B. Koenderink ${ }^{3}$, \\ Heidi Kidron ${ }^{1 *}$ \\ ${ }^{1}$ Division of Pharmaceutical Biosciences, Faculty of Pharmacy, University of Helsinki, P.O. Box 56, 00014 \\ Helsinki, Finland \\ ${ }^{2}$ Current address: Department of Clinical Pharmacology, Faculty of Medicine, University of Helsinki \\ ${ }^{3}$ Radboud University Medical Center, Department of Pharmacology and Toxicology, Nijmegen, The \\ Netherlands \\ *corresponding author \\ Telephone: +358405666660 \\ Email: heidi.kidron@helsinki.fi
}

\section{SUPPORTING INFORMATION}

Figure S1: Time-dependent uptake of DBF and estrone sulfate

Tables S1 and S2: Data used to analyze concentration-dependent uptake of DBF and estrone sulfate

Figure S2: DBF fluorescence interference with food additives $(50 \mu \mathrm{M})$

Figure S3: Solubility of food additives $(50 \mu \mathrm{M})$ in transport buffer

Figure S4: Structural formulas of the food additives that were identified as OATP2B1 inhibitors

Table S3: Molecular properties of the tested food additives

Table S4: Inhibition of OATP2B1-mediated uptake by food additives $(50 \mu \mathrm{M})$ and comparison with results from study by Zou et al. ${ }^{1}$ 

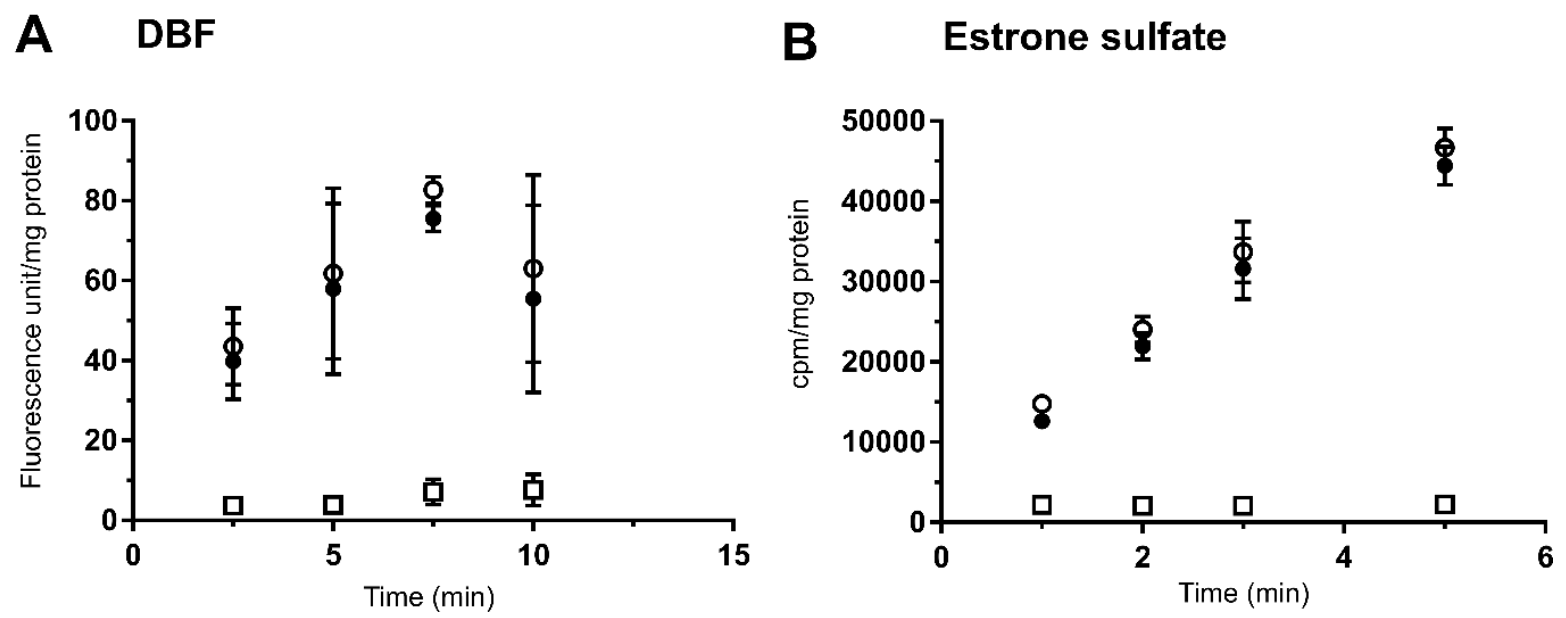

Figure S1. Time-dependent uptake of (A) $1 \mu \mathrm{M}$ dibromofluorescein (DBF) and (B) $0.5 \mu \mathrm{M}$ estrone sulfate into HEK293 cells expressing OATP2B1 (O) or control ( $\square$ ). OATP2B1-mediated transport $(\bullet)$ was obtained by subtracting control uptake from OATP2B1 uptake. Uptake of DBF and estrone sulfate were studied at $\mathrm{pH} 7.4$ and $\mathrm{pH} 5.5$, respectively. The data is presented as mean \pm SD from one study with three replicate wells. 
Table S1. Data used to analyze concentration-dependent uptake of DBF into OATP2B1 and control (eYFP) expressing HEK293 cells. OATP2B1-mediated uptake was obtained by subtracting control uptake from OATP2B1 uptake. The data is presented as mean \pm SD from one study with three replicate wells.

\begin{tabular}{llll}
\hline $\begin{array}{l}\text { DBF } \\
\text { concentration } \\
(\mu \mathrm{M})\end{array}$ & $\begin{array}{l}\text { OATP2B1 uptake } \\
\text { (fluorescence unit/ } \\
\text { mg total protein/min) }\end{array}$ & $\begin{array}{l}\text { Control (eYFP) uptake } \\
\text { (fluorescence unit/ } \\
\text { mg total protein/min) }\end{array}$ & $\begin{array}{l}\text { OATP2B1-mediated uptake } \\
\text { (fluorescence unit/ } \\
\text { mg total protein/min) }\end{array}$ \\
\hline 0.01 & $1.72 \pm 0.91$ & $1.15 \pm 0.68$ & $0.56 \pm 1.13$ \\
0.1 & $13.89 \pm 0.31$ & $1.60 \pm 0.93$ & $12.29 \pm 0.98$ \\
0.5 & $54.13 \pm 6.53$ & $1.43 \pm 0.24$ & $52.70 \pm 6.53$ \\
2.5 & $171.65 \pm 23.15$ & $5.30 \pm 0.84$ & $166.36 \pm 23.17$ \\
5 & $202.29 \pm 18.00$ & $7.37 \pm 0.75$ & $194.92 \pm 18.01$ \\
15 & $303.79 \pm 16.36$ & $25.17 \pm 0.44$ & $278.61 \pm 16.37$ \\
30 & $356.22 \pm 15.50$ & $58.85 \pm 9.98$ & $297.37 \pm 18.43$ \\
\hline
\end{tabular}

Table S2. Data used to analyze concentration-dependent uptake of estrone sulfate into OATP2B1 and control (eYFP) expressing HEK293 cells. OATP2B1-mediated uptake was obtained by subtracting control uptake from OATP2B1 uptake. The data is presented as mean \pm SD from one study with three replicate wells.

\begin{tabular}{llll}
\hline $\begin{array}{l}\text { Estrone sulfate } \\
\text { concentration } \\
(\mu \mathrm{M})\end{array}$ & $\begin{array}{l}\text { OATP2B1 uptake } \\
(\mathrm{pmol} / \mathrm{mg} \text { total protein/min) }\end{array}$ & $\begin{array}{l}\text { Control (eYFP) uptake } \\
(\mathrm{pmol} / \mathrm{mg} \text { total protein/min) }\end{array}$ & $\begin{array}{l}\text { OATP2B1-mediated uptake } \\
(\mathrm{pmol} / \mathrm{mg} \text { total protein/min })\end{array}$ \\
\hline 0.1 & $0.63 \pm 0.09$ & $0.10 \pm 0.02$ & $0.53 \pm 0.09$ \\
0.5 & $9.52 \pm 0.18$ & $0.65 \pm 0.23$ & $8.88 \pm 0.18$ \\
1 & $23.66 \pm 4.61$ & $1.12 \pm 0.06$ & $22.54 \pm 4.61$ \\
5 & $127.10 \pm 18.58$ & $4.77 \pm 0.54$ & $122.33 \pm 18.58$ \\
15 & $310.56 \pm 83.48$ & $8.71 \pm 1.53$ & $301.85 \pm 83.48$ \\
30 & $388.16 \pm 54.89$ & $17.37 \pm 4.78$ & $370.78 \pm 54.89$ \\
50 & $486.40 \pm 69.01$ & $40.15 \pm 18.11$ & $446.24 \pm 69.01$ \\
80 & $508.95 \pm 80.73$ & $84.26 \pm 32.57$ & $424.69 \pm 80.73$ \\
\hline
\end{tabular}




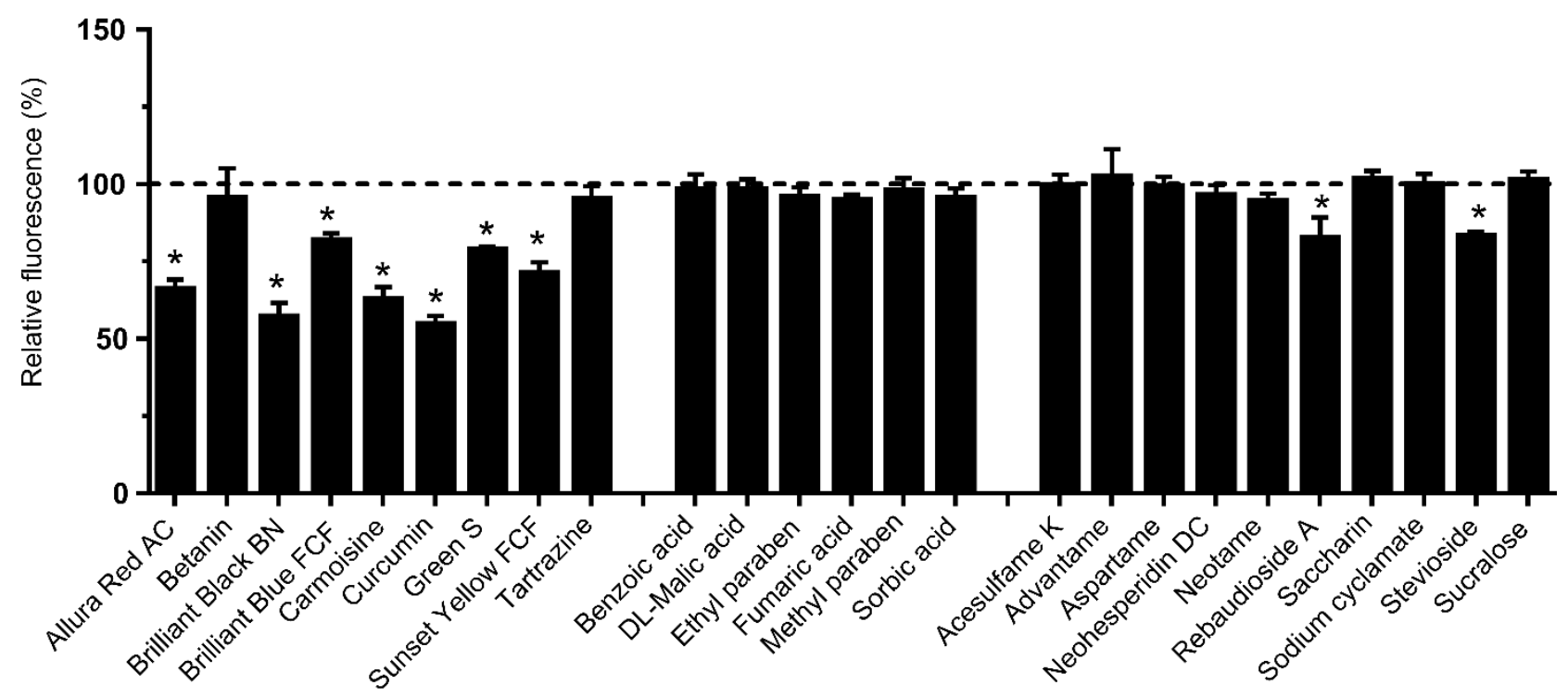

${ }^{*} \mathrm{p}<0.05$, compared to control

Figure S2. Interference of food additives with dibromofluorescein (DBF) fluorescence assuming that food additives are completely retained in the final fluorescence sample. DBF $(0.1 \mu \mathrm{M})$ fluorescence was measured with $50 \mu \mathrm{M}$ food additive in $0.1 \mathrm{M} \mathrm{NaOH}$. Results are expressed as mean $\pm \mathrm{SD}$ of three replicate measurements normalized to control without food additive.

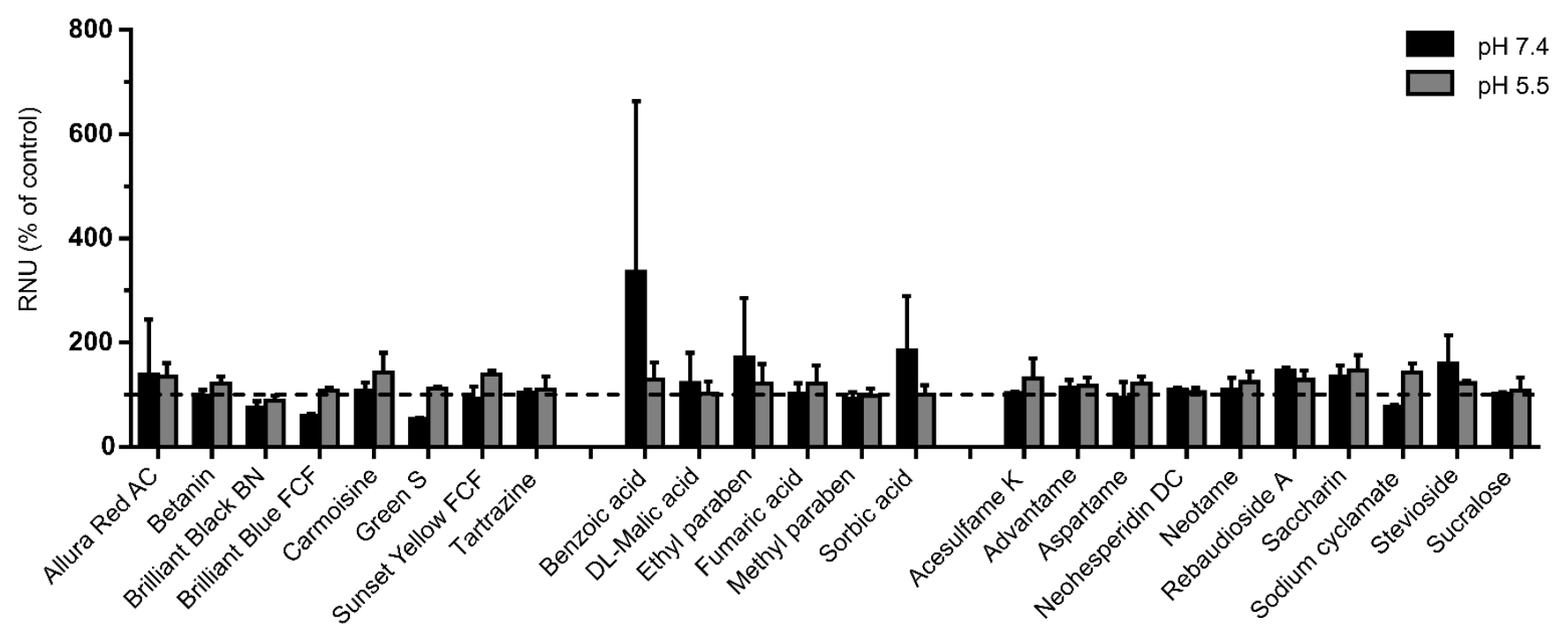

Figure S3. Solubility of food additives $(50 \mu \mathrm{M})$ in transport buffer $\mathrm{pH} 7.4$ or $\mathrm{pH} 5.5$ measured with nephelometry. Results are expressed as mean \pm SD (three replicates) relative nephelometric unit (RNU) of food additives in transport buffer normalized to RNU of transport buffer alone. 
ALLURA RED AC<smiles>COc1cc(S(=O)(=O)O[Na])c(C)cc1N=Nc1c(O)ccc2cc(S(N)(=O)=O)ccc12</smiles>

BRILLIANT BLACK BN

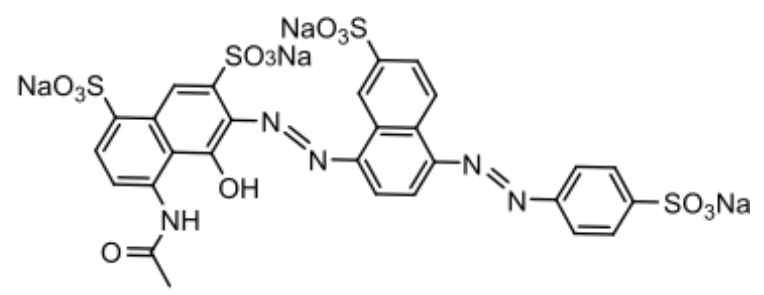

BRILLIANT BLUE FCF<smiles>CCN(Cc1cccc(S(=O)(=O)O[Na])c1)c1ccc(C(=C2C=CC(=[N+](CC)Cc3cccc(S(C)(=O)=O)c3)C=C2)c2ccccc2[O-])cc1</smiles>

CURCUMIN<smiles>COc1cc(/C=C/C(=O)CC(=O)/C=C/c2ccc(O)c(OC)c2)ccc1O</smiles>

\section{CARMOISINE}

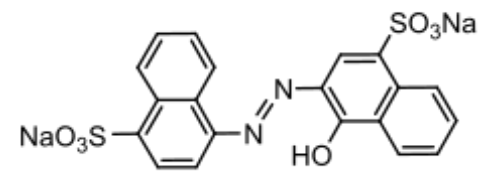

NEOHESPERIDIN DC

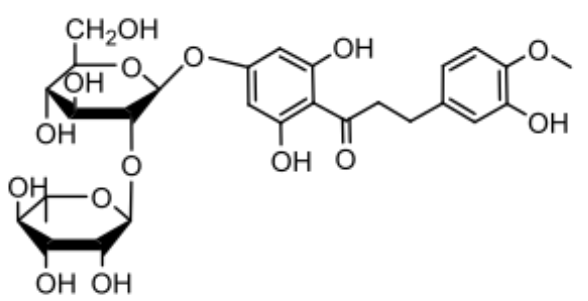

\section{SUNSET YELLOW FCF}<smiles>O=S(=O)(O[Na])c1ccc(N=Nc2c(O)ccc3cc(S(=O)(=O)O[Na])ccc23)cc1</smiles>

Figure S4. Structural formulas of the food additives that were identified as OATP2B1 inhibitors. 
Table S3. Molecular properties of the tested food additives. The properties were calculated with ACD/Labs version 8.0 (Advanced Chemistry Development, Inc., Toronto, ON, Canada) for the parent compound.

\begin{tabular}{|c|c|c|c|c|c|c|}
\hline Food additive & $\begin{array}{l}\text { Catalog } \\
\text { number }\end{array}$ & E number & $\begin{array}{l}\text { MW } \\
(\mathrm{g} / \mathrm{mol})\end{array}$ & PSA & $\log D_{7.4}$ & $\log D_{5.5}$ \\
\hline Acesulfame K (potassium salt) & 47134 & E 950 & 163 & 81 & -2.32 & -2.32 \\
\hline Advantame (monohydrate) & 80054 & E 969 & 459 & 134 & -0.25 & -0.03 \\
\hline Allura Red AC (sodium salt) & 38213 & E 129 & 452 & 180 & -1.64 & -1.64 \\
\hline Aspartame & 47135 & E 951 & 294 & 119 & -1.49 & -1.34 \\
\hline Benzoic acid & 33047 & E 210 & 122 & 37 & -0.98 & 0.58 \\
\hline Betanin (red beet extract diluted with dextrin) & CDS000584 & E 162 & 551 & 247 & -6.59 & -6.42 \\
\hline Brilliant Black BN (sodium salt) & 11220 & E 151 & 780 & 350 & -7.64 & -7.64 \\
\hline Brilliant Blue FCF (sodium salt) & 80717 & E 133 & 750 & 195 & -0.18 & -0.17 \\
\hline Carmoisine (sodium salt) & 52245 & E 122 & 458 & 170 & -3.1 & -3.07 \\
\hline Curcumin & C1386 & E 100 & 368 & 93 & 2.84 & 2.92 \\
\hline DL-Malic acid & 240176 & Е 296 & 134 & 95 & -5.99 & -3.9 \\
\hline Ethylparaben & 111988 & E 214 & 166 & 47 & 2.34 & 2.39 \\
\hline Fumaric acid & 47910 & Е 297 & 116 & 75 & -4.75 & -3.09 \\
\hline Green $\mathrm{S}$ (sodium salt) & 06737 & E 142 & 556 & 152 & 0.98 & 1.25 \\
\hline Methylparaben & H5501 & E 218 & 152 & 47 & 1.81 & 1.86 \\
\hline Neohesperidin dihydrochalcone & 75041 & E 959 & 613 & 245 & 2.59 & 3.08 \\
\hline Neotame & 49777 & E 961 & 378 & 105 & 1.07 & 1.17 \\
\hline Rebaudioside A & 01432 & E 960 & 967 & 374 & -1.12 & -1.12 \\
\hline Saccharin & 109185 & E 954 & 183 & 72 & -1.09 & -1.08 \\
\hline Sodium cyclamate (sodium salt) & 47827 & E 952 & 179 & 75 & -2.52 & -2.4 \\
\hline Sorbic acid & S1626 & E 200 & 112 & 37 & -1.41 & 0.39 \\
\hline Stevioside (hydrate) & S3572 & E960 & 805 & 295 & 1.19 & 1.19 \\
\hline Sucralose & PHR1342 & E 955 & 398 & 129 & 0.68 & 0.68 \\
\hline Sunset Yellow FCF (sodium salt) & 465224 & E 110 & 408 & 170 & -3.3 & -3.3 \\
\hline Tartrazine (sodium salt) & 03322 & E 102 & 468 & 220 & -6.63 & -6.63 \\
\hline
\end{tabular}

MW, molecular weight; PSA, polar surface area 
Table S4. Inhibition of OATP2B1-mediated uptake of dibromofluorescein (DBF; $1 \mu \mathrm{M})$ at $\mathrm{pH} 7.4$, and estrone sulfate $(\mathrm{ES} ; 0.5 \mu \mathrm{M})$ at $\mathrm{pH} 5.5$ by food additives at $50 \mu \mathrm{M}$ concentration. Results are expressed as mean \pm SD of OATP2B1-mediated uptake relative to control with DBF or estrone sulfate alone from one experiment with three replicates. For comparison, results from the study by Zou et al. ${ }^{1}$ are presented.

\begin{tabular}{|c|c|c|c|c|c|c|}
\hline Food additive & $\begin{array}{l}\text { DBF uptake } \\
\text { (pH 7.4) } \\
\text { (\% of control) }\end{array}$ & $\begin{array}{l}\text { ES uptake } \\
\text { (pH 5.5) } \\
\text { (\% of control) }\end{array}$ & $\begin{array}{l}\text { Zou et al. }{ }^{1} \\
\text { DBF uptake } \\
(\% \text { of control })\end{array}$ & $\begin{array}{l}\mathbf{K}_{\mathbf{i}} \\
(\mathrm{DBF} \mathbf{p H} 7.4) \\
(\mu \mathrm{M})\end{array}$ & $\begin{array}{l}\mathbf{K}_{\mathbf{i}} \\
(\mathrm{ES} \mathbf{p H} 5.5) \\
(\mu \mathrm{M})\end{array}$ & $\begin{array}{l}\text { Zou et al. }{ }^{1} K_{\mathbf{i}} \\
(\mu \mathrm{M})\end{array}$ \\
\hline Acesulfame K & $91.7 \pm 2.8$ & $94.2 \pm 9.8$ & $101(10 \mu \mathrm{M})$ & $\mathrm{a}$ & $\mathrm{a}$ & $\mathrm{a}$ \\
\hline Advantame & $91.5 \pm 6.5$ & $91.3 \pm 9.9$ & $\mathrm{a}$ & a & $\mathrm{a}$ & a \\
\hline Allura Red AC & $5.3 \pm 1.0$ & $4.4 \pm 1.1$ & $3.5(200 \mu \mathrm{M})$ & 0.6 & 1.5 & 2.59 \\
\hline Aspartame & $92.5 \pm 7.1$ & $92.0 \pm 10.8$ & $103(200 \mu \mathrm{M})$ & $\mathrm{a}$ & a & a \\
\hline Benzoic acid & $71.9 \pm 4.0$ & $86.0 \pm 3.4$ & a & a & a & a \\
\hline Betanin & $129.7 \pm 32.9$ & $97.3 \pm 8.0$ & a & a & $\mathrm{a}$ & a \\
\hline Brilliant Black BN & $115.5 \pm 13.2$ & $3.6 \pm 2.0$ & a & a & 3.8 & a \\
\hline Brilliant Blue FCF & $84.7 \pm 6.0$ & $13.1 \pm 9.6$ & $19.5(200 \mu \mathrm{M})$ & a & 17.7 & 13.0 \\
\hline Carmoisine & $33.0 \pm 6.9$ & $5.5 \pm 1.9$ & a & 7.0 & 2.7 & a \\
\hline Curcumin & $7.0 \pm 0.8$ & $7.4 \pm 1.9$ & a & 5.0 & 5.3 & a \\
\hline DL - Malic acid & $80.3 \pm 12.9$ & $101.0 \pm 11.4$ & $\begin{array}{l}\mathrm{D}-(+)=96.6(200 \mu \mathrm{M}) \\
\mathrm{L}-(-)=92.5(200 \mu \mathrm{M})\end{array}$ & a & a & a \\
\hline Ethyl paraben & $147.7 \pm 22.7$ & $88.6 \pm 4.1$ & $74.6(200 \mu \mathrm{M})$ & a & a & a \\
\hline Fumaric acid & $141.4 \pm 9.7$ & $93.1 \pm 4.9$ & $88.9(200 \mu \mathrm{M})$ & a & $\mathrm{a}$ & $\mathrm{a}$ \\
\hline Green $\mathrm{S}$ & $128.9 \pm 19.2$ & $83.6 \pm 8.4$ & $\mathrm{a}$ & a & a & a \\
\hline Methyl paraben & $126.3 \pm 8.7$ & $91.9 \pm 14.8$ & $92.2(200 \mu \mathrm{M})$ & a & a & a \\
\hline Neohesperidin DC & $37.0 \pm 5.4$ & $20.9 \pm 0.6$ & $14.7(200 \mu \mathrm{M})$ & 35.4 & 14.9 & 20.1 \\
\hline Neotame & $74.2 \pm 9.8$ & $91.3 \pm 13.8$ & $67.1(200 \mu \mathrm{M})$ & a & a & a \\
\hline Rebaudioside A & $43.5 \pm 2.2$ & $91.5 \pm 7.3$ & $\mathrm{a}$ & $\mathrm{a}$ & $\mathrm{a}$ & a \\
\hline Saccharin & $69.9 \pm 11.8$ & $82.9 \pm 2.7$ & $97.1(200 \mu \mathrm{M})$ & a & $\mathrm{a}$ & a \\
\hline Sodium cyclamate & $78.1 \pm 15.3$ & $98.0 \pm 7.3$ & a & a & a & a \\
\hline Sorbic acid & $77.1 \pm 3.1$ & $92.8 \pm 7.5$ & $\mathrm{a}$ & a & a & a \\
\hline Stevioside & $73.8 \pm 5.8$ & $109.1 \pm 3.6$ & a & $\mathrm{a}$ & $\mathrm{a}$ & a \\
\hline Sucralose & $153.5 \pm 8.9$ & $90.2 \pm 3.5$ & $102(1000 \mu \mathrm{M})$ & a & a & a \\
\hline Sunset Yellow FCF & $71.3 \pm 6.3$ & $28.5 \pm 10.6$ & $45.5(50 \mu \mathrm{M})$ & a & 19.6 & 68.4 \\
\hline Tartrazine & $84.9 \pm 17.5$ & $80.0 \pm 4.6$ & $97.8(200 \mu \mathrm{M})$ & $\mathrm{a}$ & a & a \\
\hline
\end{tabular}

\section{${ }^{a}$ Not determined}

${ }^{\mathrm{b}}$ Screening concentration in parenthesis 


\section{REFERENCES}

(1) Zou, L.; Spanogiannopoulos, P.; Pieper, L. M.; Chien, H.-C.; Cai, W.; Khuri, N.; Pottel, J.; Vora, B.; Ni, Z.; Tsakalozou, E.; Zhang, W.; Shoichet, B. K.; Giacomini, K. M.; Turnbaugh, P. J. Bacterial Metabolism Rescues the Inhibition of Intestinal Drug Absorption by Food and Drug Additives. Proc. Natl. Acad. Sci. U. S. A. 2020, 117 (27), 16009-16018. 